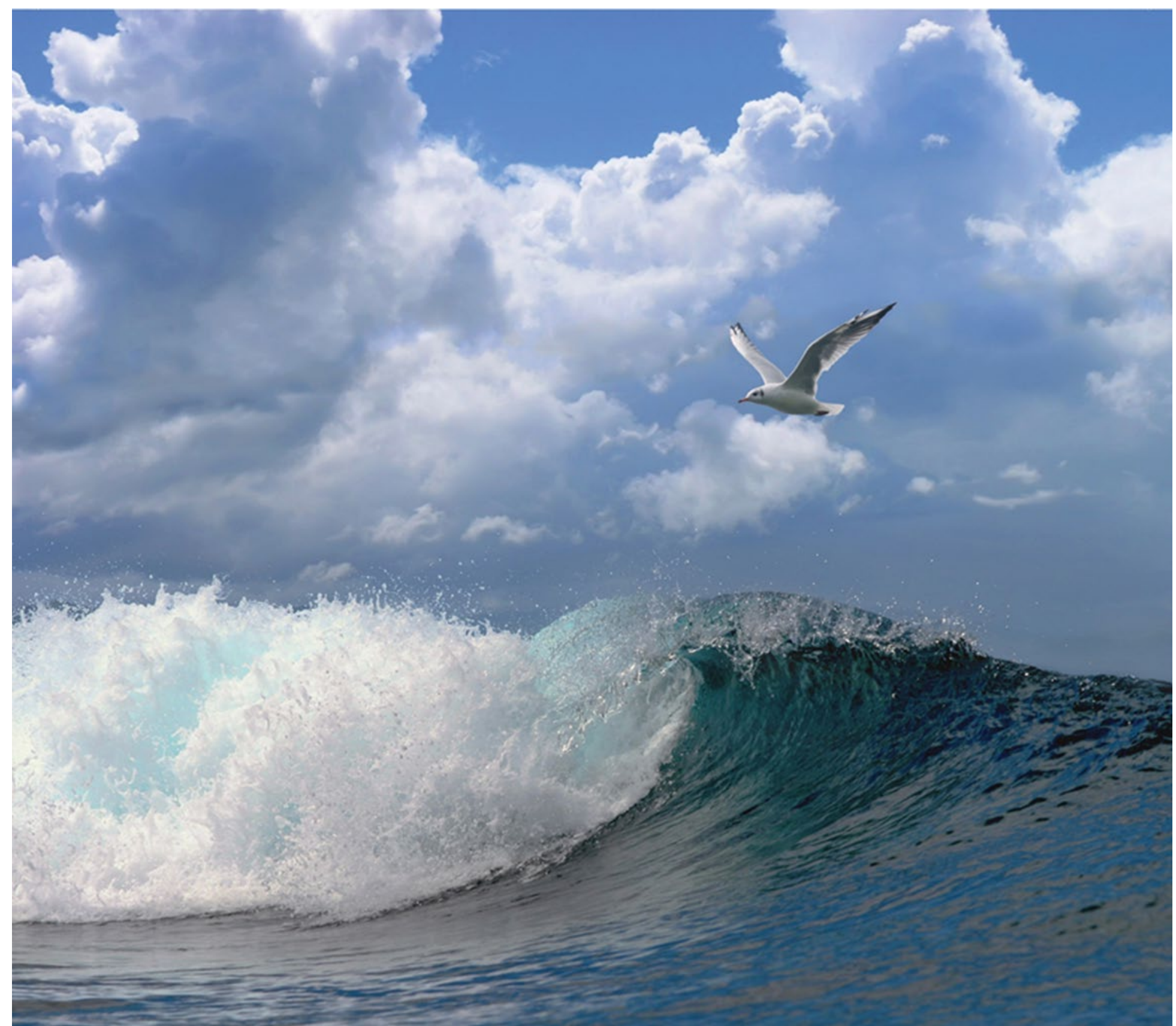

\title{
Offshorewindpark Borssele en medegebruik: overwegingen op basis van expert judgement
}




\section{Offshorewindpark Borssele en medegebruik: overwegingen op basis van expert judgement}

Auteur(s): $\quad$ Erwin Winter, Marcel Rozemeijer, Oscar Bos, met bijdragen van Lisanne van den Bogaart en Pauline Kamermans

Dit onderzoek is uitgevoerd door Wageningen Marine Research en gesubsidieerd door het Ministerie van Landbouw, Natuur en Voedselkwaliteit, in het kader van het Beleidsondersteunend onderzoekthema 'Duurzame Noordzee' (projectnummer Kennisdesk BO-43-116.01-000) 
Keywords: Kabeljauw, kreeft, krab, offshorewindpark

Opdrachtgever: Ministerie van LNV

T.a.v.: E. Knegtering

Postbus 20401

2500 EK Den Haag

BO-43-116.01-000

Dit rapport is gratis te downloaden van https://doi.org/10.18174/550017

Wageningen Marine Research verstrekt geen gedrukte exemplaren van rapporten.

Wageningen Marine Research is ISO 9001:2015 gecertificeerd.

\section{(c) Wageningen Marine Research}

Wageningen Marine Research, instituut binnen de rechtspersoon Stichting

Wageningen Research, hierbij

vertegenwoordigd door

Dr.ir. J.T. Dijkman, Managing director

KvK nr. 09098104,

WMR BTW nr. NL 8113.83.696.B16.

Code BIC/SWIFT address: RABONL2U

IBAN code: NL 73 RABO 0373599285
Wageningen Marine Research aanvaardt geen aansprakelijkheid voor gevolgschade, noch voor schade welke voortvloeit uit toepassingen van de resultaten van werkzaamheden of andere gegevens verkregen van Wageningen Marine Research. Opdrachtgever vrijwaart Wageningen Marine Research van aanspraken van derden in verband met deze toepassing.

Alle rechten voorbehouden. Niets uit deze uitgave mag weergegeven en/of gepubliceerd worden, gefotokopieerd of op enige andere manier gebruikt worden zonder schriftelijke toestemming van de uitgever of auteur. 


\section{Inhoud}

1.1 Medegebruik in windparken op zee

1.2 Natuurinclusief-bouwen in windparken op zee $\quad 6$

1.3 WEG Borssele

$\begin{array}{lll}1.4 & \text { Borssele, kavel II } & 7\end{array}$

$\begin{array}{lll}1.5 & \text { Probleemstelling } & 9\end{array}$

$\begin{array}{lll}1.6 & \text { Kennisvragen } & 9\end{array}$

2 Methode $r$

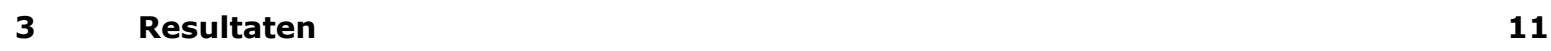

3.1 Interacties en overwegingen m.b.t. natuurinclusief bouwen en medegebruik in WEG Borssele 11

$\begin{array}{ll}3.2 & \text { Kabeljauw } \\ & 3.2 .13\end{array}$

3.2.1 Effect van kunstriffen op samenstelling visfauna $\quad 13$

3.2.2 Gedrag en bewegingspatronen binnen windparken $\quad 14$

3.2.3 Mogelijke effecten van passieve visserij 17

3.2.4 Mogelijke kansen van passieve visserij 17

$\begin{array}{ll}3.2 .5 & \text { Voorstel visserijvrije zone }\end{array}$

$\begin{array}{llr}3.3 & \text { Europese zeekreeft } & 19\end{array}$

$\begin{array}{ll}3.3 .1 & \text { Inleiding }\end{array}$

3.3.2 Effect van kunstriffen op kreeften $\quad 20$

$\begin{array}{ll}\text { 3.3.3 Gedrag en bewegingspatronen } & 20\end{array}$

$\begin{array}{lll}3.3 .4 & \text { Territoria } & 21\end{array}$

3.3.5 Mogelijke effecten van passieve visserij op de kreeften $\quad 22$

3.3.6 Mogelijke kansen van passieve visserij 23

3.3.7 Voorstel visserijvrije zone vanuit het belang van het kreeftonderzoek 23

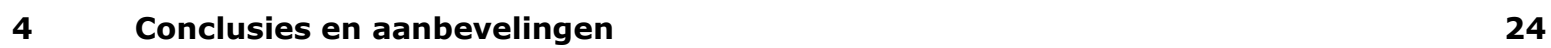

4.1 Natuurinclusief bouwen en medegebruik in WEG Borssele 24

4.2 Directe beïnvloeding van passieve visserij op het uitvoeren van het lopende telemetrieonderzoek naar kabeljauw in kavel II $\quad 25$

4.3 Directe beïnvloeding van passieve visserij op het uitvoeren van geplande telemetrie$\begin{array}{ll}\text { onderzoeken naar Europese zeekreeft } & 25\end{array}$

$\begin{array}{lll}4.4 & \text { Aanbevelingen } & 26\end{array}$

$\begin{array}{llr}5 & \text { Dankwoord } & 27\end{array}$

$\begin{array}{llr}6 & \text { Kwaliteitsborging } & 28\end{array}$

$\begin{array}{lr}\text { Literatuur } & 29\end{array}$

$\begin{array}{ll}\text { Verantwoording } & 32\end{array}$ 


\section{Samenvatting}

Met het oog op meervoudig ruimtegebruik is besloten om windparken open te stellen voor de volgende mogelijke vormen van medegebruik: 1) Maricultuur (schelp- en schaaldieren en zeewier); 2) Alternatieve vormen van duurzame energieopwekking en -opslag (zonne- of getijdenenergie); 3 ) Natuurbevorderende projecten (platte-oesterherstel, schuilplekken voor vissen, kunstriffen); en 4) Passieve visserij (lijnen voor vis en korven voor krabben en kreeften). In de richtlijn 'Handreiking Gebiedspaspoort' Borssele is aangegeven welk medegebruik binnen bepaalde windenergiegebieden de voorkeur heeft. Op basis van gebiedsspecifieke kenmerken binnen een windenergiegebied (WEG) wordt bepaald welke vormen van medegebruik het gunstigste perspectief hebben en het best zijn in te passen. Vervolgens kan in het Afwegingskader Medegebruik van windparken op zee onderscheid worden gemaakt tussen de vergunningaanvragen van potentiële medegebruikers.

Daarnaast vinden er natuurinclusiefbouwenprojecten plaats in windparken. Het doel is om een bijdrage te leveren aan versterking van een gezonde zee en van behoud en duurzaam gebruik van biodiversiteit: soorten en habitats die van nature in Nederland voorkomen. Vergunninghouders dienen zich aantoonbaar in te spannen om het windpark zodanig te ontwerpen en te realiseren dat het park actief hieraan bijdraagt. Ze maken daartoe plannen die door het ministerie van LNV (portefeuille Natuur) inhoudelijk goed moeten worden gekeurd.

WEG Borssele is het eerste grootschalige gebied voor opwekking van windenergie die met toepassing van de vigerende Wet windenergie op zee in gebruik wordt genomen en bestaat uit 4 kavels met offshorewindparken (kavels I, II, III en IV) en 1 kavel met een innovatiegebied (V). Kavels I en II (Ørsted) zijn sinds 2020 operationeel en kavels III en IV (Blauwwind) sinds 2021. In het gebied heeft het Rijk middels voorschriften in kavelbesluiten experimentele natuurinclusiefbouwenprojecten gestimuleerd voor kabeljauw (Borssele I + II) en platte oesters (Borssele III + IV en Borssele V) die conform inmiddels goedgekeurde plannen van aanpak dienen te worden uitgevoerd en gemonitord.

Het ministerie van LNV heeft de volgende kennisvragen gesteld voor WEG Borssele: 1) Kan het voorgestelde medegebruik (passieve visserij en maricultuur) in WEG Borssele nadelen opleveren voor (doelen van) de natuurinclusiefbouwenproject en? 2) Kan het voorgestelde medegebruik synergiekansen bieden voor de natuurinclusiefbouwenprojecten en welke worden mogelijk gemist? En meer speciek voor Borssele kavel II: 1) onder welke voorwaarden is passieve visserij verenigbaar met (doelen van) het natuurinclusiefbouwenproject voor "kabeljauw"? 2) Welke invloed heeft passieve visserij op het uitvoeren van het lopende telemetrie-onderzoek naar kabeljauw en Europese zeekreeft?

Binnen deze korte kennisvraagopdracht zijn de meer algemene vragen ingevuld op basis van expert judgement zonder uitgebreide onderbouwing. Positieve en negatieve interacties tussen medegebruik en natuurherstel zijn weergegeven in een overzichtstabel. De effecten van medegebruik door passieve visserij op de doelen binnen natuurinclusief-bouwprojecten in kavel II en het onderzoek hiernaar voor kabeljauw en Europese zeekreeft is specifieker benaderd en omvat een overzicht van kennis over gedrag, habitatgebruik en schaalgroottes voor kabeljauw en Europese zeekreeft. Deze rapportage betreft een eerste quickscan.

In het algemeen lijkt het in de Handreiking gebiedspaspoort Borssele voorgestelde medegebruik binnen verschillende kavels geen nadelen op te leveren voor de voor die kavels eerder vastgestelde doelen voor natuurinclusief bouwen, uitgezonderd in kavel II (passieve visserij versus doelen voor bevordering van kabeljauw). Verder kunnen "maricultuur" en "duurzame energie" (kavel III) nadelen opleveren voor doelen voor bevordering van platte oesters in dezelfde kavel, wanneer daar zeer grootschalig zeewier- of schelpdierkweek zou plaatsvinden of zeer grootschalig zonnepanelen zouden worden geplaatst. 
Er liggen ook synergiekansen met natuurinclusiefbouwen-doelen bij de huidige functietoedelingen, met name bij "maricultuur" (kavel III) zoals zeewierkweek en schelpdierkweek (in het bijzonder van platte oesters, door extra oester-recruits) en de bevordering van platte oesters in dezelfde kavels. Verder liggen er synergiekansen die bij de huidige functietoedelingen in de Handreiking gebiedspaspoort Borssele niet kunnen worden benut zoals "maricultuur" in een kavel met doelen voor bevordering van kabeljauw bij toepassing van zeewierkweek of schelpdierkweek. Ook passieve visserij en maricultuur kan waarschijnlijk goed gecombineerd worden.

Het aanbrengen van een groter areaal hard substraat in bepaalde kavels middels kabeljauwstructuren (kunstriffen) of maatregelen voor platte oesterherstel kunnen leiden tot hogere lokale omvang van populaties van bepaalde doelsoorten zoals kabeljauw en kreeft. Als er goed inzicht is in welke structuren hard substraat de habitatkwaliteit voor de diverse doelsoorten verhoogd wordt, zal ook de lokale productie en populatie omvang kunnen worden verhoogd. Alleen directe benutting van doelsoorten op locaties waar deze door natuurinclusief-bouwen worden versterkt, zoals bijvoorbeeld passieve visserij in kavel II, kan de lokale extra productie van doelsoorten, zoals kabeljauw en kreeft, te niet worden gedaan door snelle lokale uitputting, omdat deze soorten grotendeels honkvast zijn en zich over relatief kleine afstanden bewegen. In hoeverre activiteiten die samenhangen met medegebruik ook het gedrag van kabeljauw kunnen verstoren, zoals geluid van extra vaarbewegingen, is niet goed bekend. In Borssele kavel II is sprake van tegenstelde belangen, omdat er zowel gewerkt wordt aan het herstel van kabeljauw en kreeft en er tegelijkertijd voorgesteld wordt dezelfde soorten met passieve visserij lokaal te vangen.

Het lopende telemetrie-experiment naar (gezenderde) kabeljauwen en Europese zeekreeften kan negatief worden beïnvloed door toestaan van passieve visserij waarbij deze kunnen worden (bij)gevangen. Wanneer we alleen rekening hoeven te houden met de mogelijke effecten op het experiment met de natuurinclusiefbouwenstructuren in het deel van kavel II waar de structuren staan, lijkt instelling een (tijdelijke) visserijvrije zone van $1,5 \mathrm{~km}$ buiten de ring van windmolenturbines waarbinnen het netwerk van 16 ontvangers is opgesteld een afdoende maatregel. Wanneer het natuurinclusiefbouwenproject wordt gezien als - een eerste startpunt - voor het willen bevorderen van kabeljauw in heel kavel II dan wel in beide kavels ( + II) van de betreffende vergunninghouder, dan zou deze niet gecombineerd moeten worden met passieve visserij op vis (lijnvisserij, staand want).

Het is aan te bevelen om bij natuurinclusief-bouwen en medegebruik vooraf goed vast te stellen wat het doel hiervan is, zoals kleinschalige pilots die fungeren om van te leren voor medegebruik in andere windparken, of dat het om op zichzelf staande en effectieve oplossingen moet gaan. Binnen pilots zal en goede monitorings- en onderzoeksopzet nodig zijn om ook voor andere offshore-windparken onderbouwde keuzes hierin te maken. De schaal waar op natuurinclusief-bouwen of medegebruik wordt ingezet en de duur hiervan zou verder moeten worden uitgewerkt. Herstel van natuurlijke platte oesterriffen gaat om een grotere ruimtelijke schaal en lange termijn, terwijl toestaan van passieve visserij ook kortdurend en plaatselijk kan zijn. Ook de schaal-effecten van veel kleine riffen versus enkele grote, of effecten van schaal op een hogere productie door groter areaal hard substraat of juist vermindering door onttrekking van voedsel en nutriënten via maricultuur of beschaduwing door grote arealen zonnepanelen, is een belangrijke factor in de keuze voor eventuele vormen van medegebruik en toepassing in andere windparken.

Daarnaast zouden de hier genoemde ecologische aspecten en overwegingen moeten worden geïntegreerd met logistieke en economische kosten-batenanalyses om effectieve keuzes voor toepassing van natuurinclusief-bouwen en medegebruik van offshore-windparken te kunnen maken. 


\section{$1 \quad$ Inleiding}

\subsection{Medegebruik in windparken op zee}

In de Beleidsnota Noordzee 2016-2021 is vanuit het oogpunt van meervoudig ruimtegebruik besloten de windparken open te stellen voor medegebruik. De volgende vormen - ruimtelijk - medegebruik zijn mogelijk in windparken op zee:

- Maricultuur (onder andere schelp- en schaaldieren en zeewier)

- Alternatieve vormen van duurzame energieopwekking en -opslag (onder andere zonne- of getijdenenergie)

- Natuurbevorderende projecten (bijvoorbeeld platte-oesterherstel, schuilplekken voor vissen, kunstriffen)

- Passieve visserij (onder andere lijnen en korven voor krabben en kreeften)

Welk medegebruik binnen bepaalde windenergiegebieden de voorkeur heeft wordt vastgelegd in een 'Handreiking Gebiedspaspoort'. De Handreiking gebiedspaspoort is voornamelijk een richtlijn. In deze richtlijn worden ook belangen uit de Nationale Omgevingsvisie (NOVI) ${ }^{1}$ meegewogen: "Verbeteren en beschermen van natuur en biodiversiteit." en "Ontwikkelen van een duurzame visserij". De Handreiking gebiedspaspoort brengt een meer gelaagde structuur aan die aan nationale belangen een gebiedsgerichte uitwerking geeft. Op basis van gebieds-specifieke kenmerken binnen een windenergiegebied (WEG) wordt bepaald welke vormen van medegebruik het gunstigste perspectief hebben en het best zijn in te passen. Vervolgens kan in het Afwegingskader Medegebruik van windparken op zee onderscheid worden gemaakt tussen de vergunningaanvragen van potentiële medegebruikers. Mocht er geen behoefte zijn aan het type medegebruik dat de voorkeur geniet, dan kan de zone vrijgegeven geworden voor overig medegebruik.

\subsection{Natuurinclusief-bouwen in windparken op zee}

Natuurinclusief-bouwen van windparken wordt tot nu toe door het Rijk gestimuleerd middels voorschriften in kavelbesluiten (en ondersteunend onderzoek). Het doel is om een bijdrage te leveren aan versterking van een gezonde zee en van behoud en duurzaam gebruik van biodiversiteit: soorten en habitats die van nature in Nederland voorkomen. Vergunninghouders dienen zich aantoonbaar in te spannen om het windpark zodanig te ontwerpen en te realiseren dat het park actief hieraan bijdraagt. Ze maken daartoe plannen die door het ministerie van LNV (portefeuille Natuur) inhoudelijk goed moeten worden gekeurd.

WEG Borssele is het eerste grootschalige gebied voor opwekking van windenergie die met toepassing van de vigerende Wet windenergie op zee in gebruik wordt genomen. De concessies zijn vanaf 2016 aanbesteed. Het WEG Borssele ligt op zo'n 30 km uit de Zeeuwse Kust (Figuur 1) en bestaat uit 4 kavels met offshorewindparken (kavels I, II, III en IV) en 1 kavel met een innovatiegebied (V). Kavels I en II (Ørsted) zijn sinds 2020 operationeel en kavels III en IV (Blauwwind) sinds 2021 . Verder zorgt netbeheerder Tennet voor de stroomvoorziening. In het gebied heeft het Rijk middels voorschriften in kavelbesluiten experimentele natuurinclusiefbouwenprojecten gestimuleerd voor kabeljauw (Borssele I + II) en platte oesters (Borssele III + IV en Borssele V) die conform inmiddels goedgekeurde plannen van aanpak dienen te worden uitgevoerd en gemonitord.

\footnotetext{
${ }^{1}$ https://www.novistukken.nl/nationale+belangen+en+opgaven+fysieke+leefomgeving/nationale+belangen+en+opgaven/default.aspx
} 


\subsection{WEG Borssele}

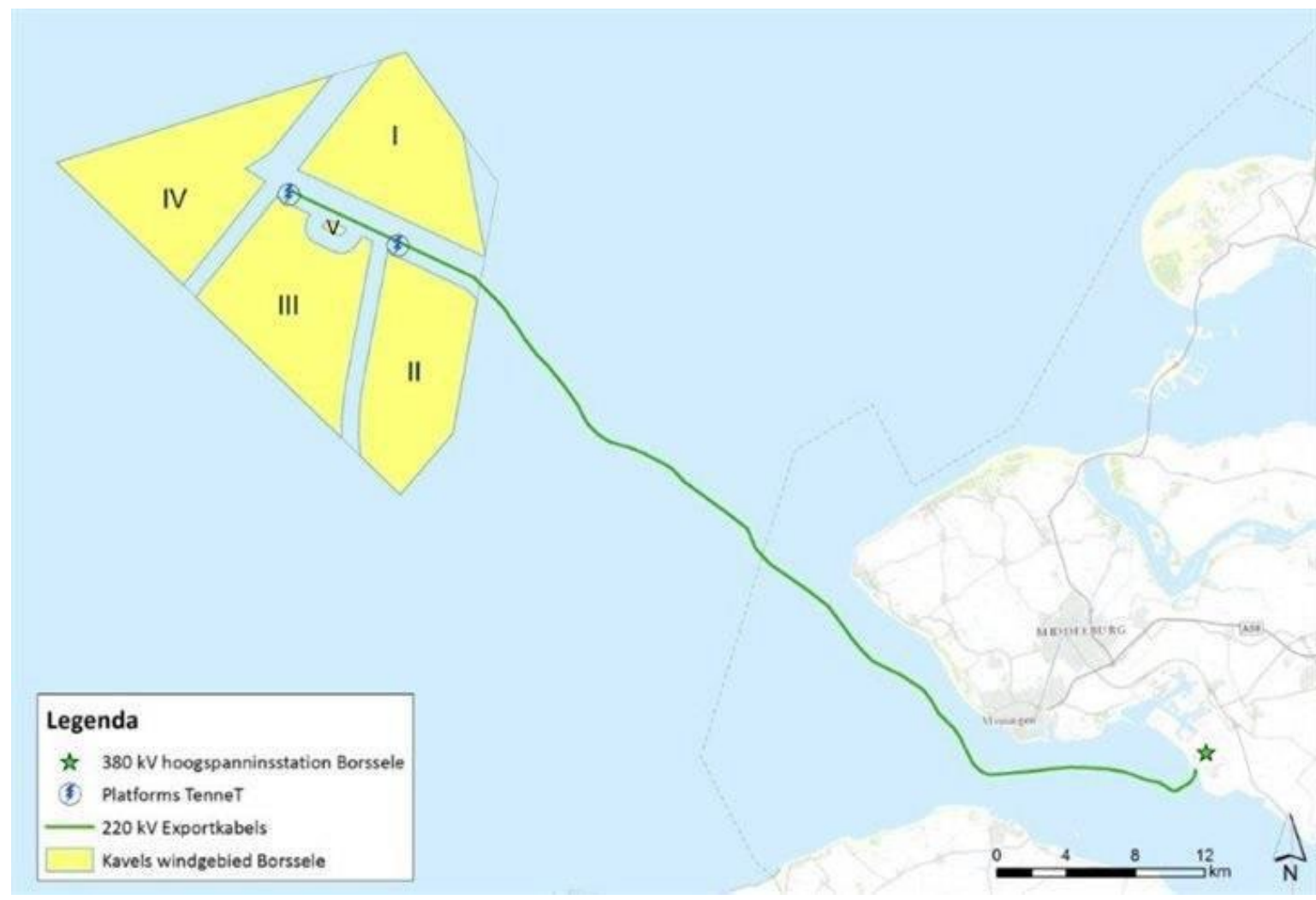

Naast de experimentele natuurinclusiefbouwenprojecten gestimuleerd voor kabeljauw en oesters, is o.I.v. het ministerie van BZK een zogeheten Handreiking gebiedspaspoort voor WEG Borssele opgesteld om volgtijdelijk delen van het gebied te bestemmen voor - ruimtelijke medegebruikfuncties, onder meer passieve visserij en maricultuur. Er zijn daarbij negatieve en positieve interacties denkbaar met de eerder geformaliseerde natuurinclusiefbouwenproject en, maar de tekst van de Handreiking gaat daar nauwelijks tot niet op in. De Handreiking gebiedspaspoort Borssele is ambtelijk vastgesteld.

Tabel 1. Voorgesteld medegebruik (in de Handreiking gebiedspaspoort Borssele) en natuurinclusiefbouwenprojecten per kavel in WEG Borssele.

\begin{tabular}{|c|c|c|c|c|}
\hline $\begin{array}{l}\text { Borssele } \\
\text { kavel }\end{array}$ & Vergunninghouder & Opmerking & $\begin{array}{l}\text { Voorgesteld } \\
\text { medegebruik }\end{array}$ & $\begin{array}{l}\text { Natuurinclusief } \\
\text { bouwen }\end{array}$ \\
\hline I & $\varnothing$ rsted & $\begin{array}{l}\text { Operationeel sinds } \\
2020\end{array}$ & $\begin{array}{l}\text { duurzame energie + } \\
\text { n.t.b }\end{array}$ & Kabeljauw \\
\hline II & $\varnothing$ rsted & $\begin{array}{l}\text { Operationeel sinds } \\
2020\end{array}$ & passieve visserij & $\begin{array}{l}\text { Kabeljauw }+ \\
\text { onderzoek Europese } \\
\text { zeekreeft }\end{array}$ \\
\hline IV & Blauwwind & $\begin{array}{l}\text { Operationeel sinds } \\
2021\end{array}$ & $\begin{array}{l}\text { natuurontwikkeling + } \\
\text { n.t.b }\end{array}$ & Platte oesters \\
\hline V & Two Towers & In ontwikkeling & $\begin{array}{l}\text { natuurontwikkeling + } \\
\text { n.t.b }\end{array}$ & Platte oesters \\
\hline
\end{tabular}

\subsection{Borssele, kavel II}

Voor Borssele, kavel II worden bij het ministerie van LNV (portefeuille Visserij en Landelijk gebied) voorbereidingen getroffen om projecten voor passieve visserij te initiëren op basis van de Handreiking. Tevens wordt er een natuurinclusiefbouwenproject ten behoeve van kabeljauw (Gadus morhua) en begeleidende biodiversiteit uitgevoerd, waarvoor door Ørsted vier kunstriffen zijn aangelegd (Figuur 
2). Het gebruik van de kunstriffen wordt door Wageningen Marine Research onderzocht door middel van gezenderde kabeljauwen die gedetecteerd worden met detectiestations. In februari 2021 is een grid met detectiestations aangelegd. In het voorjaar/zomer 2021 worden de vissen gezenderd. Het onderzoek door Wageningen Marine Research moet inzicht geven in het gebruik van de nieuwe kunstriffen door kabeljauw en hoe dit zich verhoudt tot de benutting en gedrag van kabeljauwen rondom windmolenpalen.

Bij deze kunstriffen zal ook onderzoek gedaan worden naar Europese zeekreeften (Homarus gammarus) die gezenderd worden uitgezet bij dezelfde kunstriffen en gevolgd worden met dezelfde detectiestations gedurende 2021-2022. Dit onderzoek wordt uitgevoerd door Wageningen Marine Research en is geïnitieerd vanuit Programma De Rijke Noordzee met medefinanciering door TKI WinWind.

\section{Windenergiegebied Borssele}
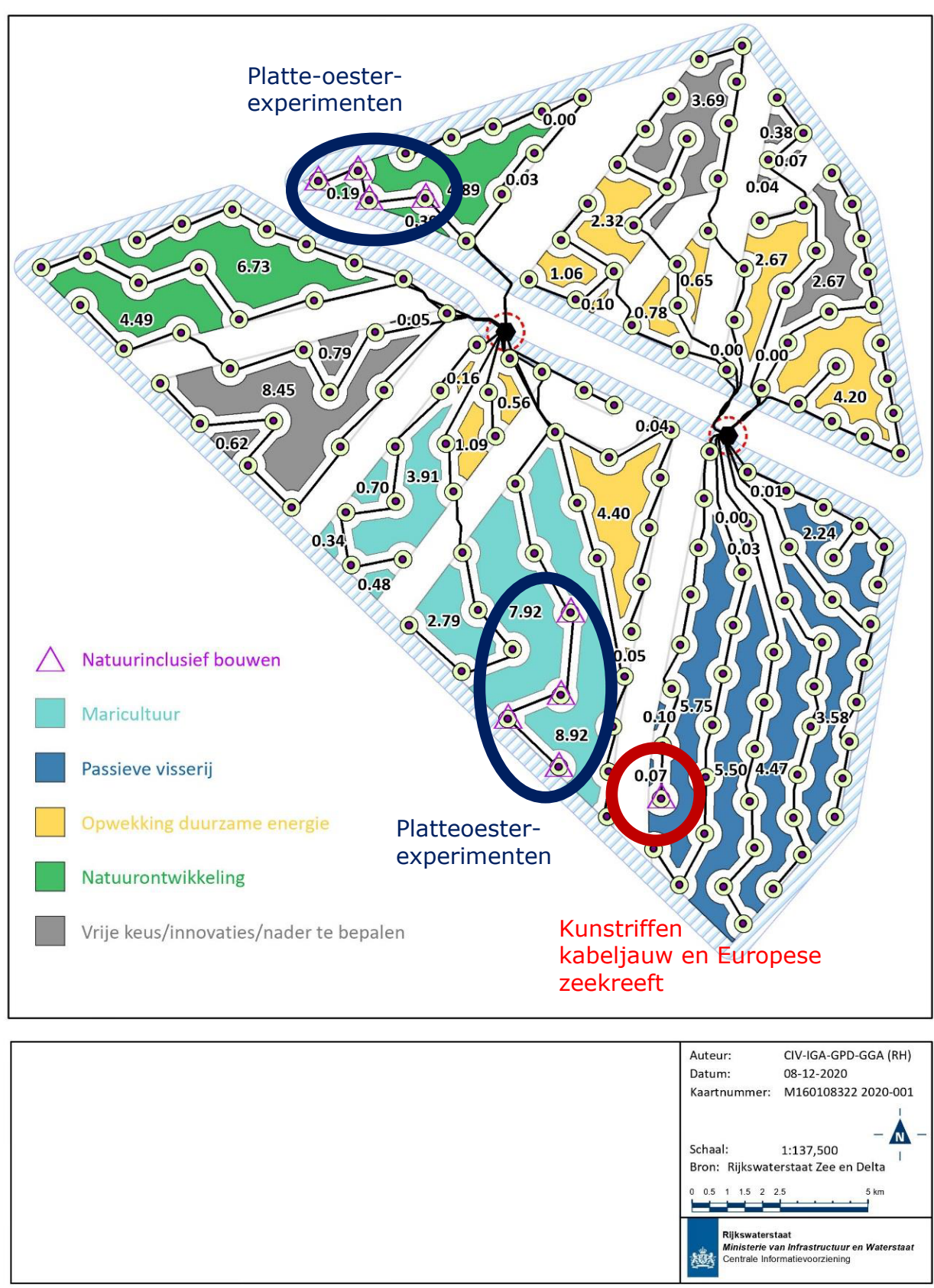

Figuur 2. Zoneringskaart met voorkeursgebieden per medegebruik activiteit windenergiegebied Borssele. Op bovenstaande zoneringskaart zijn de voorkeursgebieden per medegebruik activiteit aangegeven (bron: Handreiking gebiedspaspoort Borssele). Rood omlijnd: het deel binnen Borssele, kavel II waarin onderzoek plaatsvindt naar kabeljauw en Europese zeekreeft. 


\subsection{Probleemstelling}

De tekst in de Handreiking lijkt nauwelijks tot niet in te gaan op eventuele relaties tussen de natuurinclusiefbouwenprojecten en de functietoekenningen (Tabel 1). In het algemeen is op dit moment niet duidelijk of de voorgestelde functietoedeling nadelen kan opleveren voor de al geformaliseerde (doelen van) natuurinclusiefbouwenprojecten (alle kavels), of dat daardoor juist kansen voor synergie worden gemist. Verder is er een urgent probleem in Borssele II (zie Figuur 2): daar is het kabeljauwherstelproject en onderzoek naar Europese zeekreeft al gestart, en onduidelijk is onder welke voorwaarden passieve visserij verenigbaar is met (doelen van) het natuurinclusiefbouwenproject. De gezenderde vissen en kreeften moeten immers niet meteen opgevist worden of anderszins in hun natuurlijke gedrag worden gestoord.

\subsection{Kennisvragen}

Het ministerie van LNV heeft de volgende kennisvragen gesteld:

1. WEG Borssele:

a. Kan het in de handreiking voorgestelde medegebruik (met name passieve visserij en maricultuur) in WEG Borssele nadelen opleveren voor (doelen van) de natuurinclusiefbouwenproject en?

b. Kan het in de handreiking voorgestelde medegebruik in WEG Borssele synergiekansen bieden voor de natuurinclusiefbouwenprojecten en worden er mogelijk synergiekansen gemist doordat bepaald medegebruik voor bepaalde delen nu niet wordt voorgesteld?

2. Borssele kavel II:

a. onder welke voorwaarden is passieve visserij verenigbaar met (doelen van) het natuurinclusiefbouwenproject voor "kabeljauw"?

b. Welke invloed heeft passieve visserij op het uitvoeren van het lopende telemetrieonderzoek naar kabeljauw?

c. Welke invloed heeft passieve visserij op het uitvoeren van geplande telemetrieonderzoeken naar Europese zeekreeft? 


\section{Methode}

Binnen deze korte kennisvraagopdracht zijn de meer algemene vragen $1 \mathrm{a}$ en $1 \mathrm{~b}$ ingevuld op basis van expert judgement zonder uitgebreide onderbouwing. Inschatting van positieve en negatieve interacties tussen medegebruik en natuurherstel is gebaseerd op expert judgement en op eerdere rapporten:

- Geschiktheid zeewindparken voor maricultuur en passieve visserij: een kwalitatieve beoordeling van geschiktheid van windparklocaties voor voedselproductie (Van den Bogaart et al. 2019)

- Geschiktheid zeewindparken voor maricultuur en passieve visserij: een kwantitatieve beoordeling van de kansrijkheid van de gebieden voor de potentiële productiviteit van een selectie aan commercieel interessante soorten (Van den Bogaart et al., 2020).

De effecten van medegebruik door passieve visserij op de doelen binnen natuurinclusief-bouwprojecten in kavel II en het onderzoek hiernaar voor kabeljauw en Europese zeekreeft is specifieker benaderd en omvat een overzicht van kennis over gedrag, habitatgebruik en schaalgroottes voor kabeljauw en Europese zeekreeft. Hierbij is gebruik gemaakt van een literatuuronderzoek. Vervolgens is op basis van die kennis ingeschat hoe groot de visserijvrije zone rondom de kunstriffen minimaal moet zijn en welke (tijdelijke) maatregelen of overwegingen meegenomen kunnen worden bij de besluitvorming en uitwerking van medegebruik van windenergiegebied Borssele. Deze rapportage betreft een eerste quickscan. 


\section{Resultaten}

In de resultaten worden eerst de meer algemeen vragen over natuurinclusief bouwen en medegebruik in WEG Borssele beschouwd op basis van expert judgement. Daarna wordt voor kabeljauw en Europese kreeft op basis van beschikbare literatuur meer specifiek ingegaan op de interacties tussen natuurinclusiefbouwenprojecten en medegebruik, zowel hoe medegebruik het herstel van de doelsoorten zou kunnen beïnvloeden, als ook hoe het voorgenomen en lopend onderzoek naar de effectiviteit van natuurinclusiefbouwenprojecten voor kabeljauw en kreeft zou worden beïnvloed door het voorgestelde medegebruik.

\subsection{Interacties en overwegingen $m . b . t$. natuurinclusief bouwen en medegebruik in WEG Borssele}

In Tabel 2 is per natuurdoel weergegeven welke mogelijke voordelen en nadelen er kleven aan het toestaan van medegebruik op locaties of kavels waar aan natuurherstel gewerkt wordt en of er kansen zijn voor wederzijdse versterking of voordelen (synergie).

Tabel 2. Nadelen, voordelen en synergie van medegebruik met natuurdoelen (op basis van expert judgement).

\begin{tabular}{|c|c|c|c|c|}
\hline Natuurdoel & Medegebruik & Nadelen & Voordelen & Kansen voor synergie \\
\hline \multicolumn{5}{|l|}{ "kabeljauw" } \\
\hline \multirow[t]{5}{*}{$\begin{array}{l}\text { Kabeljauwherstel: } \\
\text { kunstriffen op } \\
\text { bodem als } \\
\text { schuilplek en } \\
\text { voedselbron (effect } \\
\text { afhankelijk van de } \\
\text { grootte van riffen) }\end{array}$} & $\begin{array}{l}\text { Passieve visserij * } \\
\text { schaaldieren } \\
\text { (krabben en } \\
\text { kreeften): korven op } \\
\text { zeebodem. }\end{array}$ & $\begin{array}{l}\text { Eventuele bijvangst } \\
\text { van de te herstellen } \\
\text { soort. In hoeverre } \\
\text { extra vaar-bewegingen } \\
\text { het gedrag van } \\
\text { kabeljauw beïnvloed is } \\
\text { nog niet goed bekend }\end{array}$ & Geen voordelen & $\begin{array}{l}\text { Geen synergie. Passieve } \\
\text { visserij op schaaldieren kan } \\
\text { herstel van kabeljauw door } \\
\text { mogelijke bijvangst negatief } \\
\text { beïnvloeden. Er is uitgebreide } \\
\text { literatuur over bijvangsten } \\
\text { van kabeljauw in verschillende } \\
\text { typen kreeftenvallen (met } \\
\text { name langs de Atlantische } \\
\text { kusten in Noord-Amerika). }\end{array}$ \\
\hline & $\begin{array}{l}\text { Passieve visserij vis: } \\
\text { kooien op } \\
\text { zeebodem, of } \\
\text { lijnvisserij }\end{array}$ & $\begin{array}{l}\text { Vangst van de te } \\
\text { herstellen soort en } \\
\text { wellicht verstoring door } \\
\text { extra vaarbewegingen } \\
\text { (nog onbekend) }\end{array}$ & Geen voordelen. & $\begin{array}{l}\text { Geen synergie. Passieve } \\
\text { visserij verstoort herstel van } \\
\text { kabeljauw door vangst van } \\
\text { deze doelsoort, en wellicht } \\
\text { indirect door verstoring van } \\
\text { gedrag door extra } \\
\text { vaaractiviteiten. }\end{array}$ \\
\hline & $\begin{array}{l}\text { Drijvende kweek } \\
\text { zeewier }\end{array}$ & $\begin{array}{l}\text { Geen nadelen; } \\
\text { mogelijk wel effect van } \\
\text { geluid van vaar- } \\
\text { bewegingen en } \\
\text { mechanisch oogsten op } \\
\text { gedrag van kabeljauw }\end{array}$ & $\begin{array}{l}\text { Extra schuilplekken } \\
\text { en voedsel }\end{array}$ & $\begin{array}{l}\text { Mogelijk synergie. } \\
\text { Zeewierkweek kan helpen om } \\
\text { herstel van kabeljauw te } \\
\text { vergroten. Effect van extra } \\
\text { vaarbewegingen en } \\
\text { mechanisch oogsten op } \\
\text { gedrag van kabeljauw is nog } \\
\text { onbekend. }\end{array}$ \\
\hline & $\begin{array}{l}\text { Drijvende kweek } \\
\text { schelpdieren } \\
\text { (mossel, oester) }\end{array}$ & $\begin{array}{l}\text { Geen nadelen; } \\
\text { mogelijk wel effect van } \\
\text { geluid van activiteiten } \\
\text { op gedrag van } \\
\text { kabeljauw }\end{array}$ & $\begin{array}{l}\text { Extra } \\
\text { schuilplekken, } \\
\text { vergroting van het } \\
\text { oppervlak } \\
\text { hardsubstraat } \\
\text { habitat en voedsel } \\
\text { voor kabeljauw }\end{array}$ & $\begin{array}{l}\text { Mogelijk synergie. Kan helpen } \\
\text { om lokale productie en } \\
\text { daarmee herstel van } \\
\text { kabeljauw te vergroten. Effect } \\
\text { van extra vaarbewegingen en } \\
\text { mechanisch oogsten op } \\
\text { gedrag van kabeljauw is nog } \\
\text { onbekend. }\end{array}$ \\
\hline & $\begin{array}{l}\text { Duurzame energie } \\
\text { (aan } \\
\text { wateroppervlak: } \\
\text { zonnepanelen, } \\
\text { getijdegeneratoren, } \\
\text { golfenergie) }\end{array}$ & $\begin{array}{l}\text { Geen nadelen } \\
\text { zonnepanelen; } \\
\text { getijdegenerator kan } \\
\text { schade aanbrengen bij } \\
\text { kabeljauw door botsing } \\
\text { met turbine-bladen; } \\
\text { geluid van golfenergie } \\
\text { kan effect hebben op } \\
\text { gedrag van kabeljauw }\end{array}$ & $\begin{array}{l}\text { Wellicht voordeel } \\
\text { door extra voedsel } \\
\text { voor kabeljauw } \\
\text { door aangroei aan } \\
\text { de structuren die } \\
\text { met de energie- } \\
\text { installaties gepaard } \\
\text { gaan. }\end{array}$ & $\begin{array}{l}\text { Synergiekansen onzeker. Hoe } \\
\text { de netto balans uitpakt voor } \\
\text { de verschillende } \\
\text { energieopwekkingsvormen is } \\
\text { niet op voorhand te zeggen. } \\
\text { Wellicht dat er door het } \\
\text { grotere oppervlak hard } \\
\text { substraat en ontbreken van } \\
\text { nadelen met name voor } \\
\text { zonnepanelen synergie te } \\
\text { verwachten is. }\end{array}$ \\
\hline
\end{tabular}




\begin{tabular}{|c|c|c|c|c|}
\hline "platte oester" & & & & \\
\hline \multirow[t]{5}{*}{$\begin{array}{l}\text { Oesterherstel: } \\
\text { platte oesters } \\
\text { geplaatst op } \\
\text { zandbodem of } \\
\text { scour protection of } \\
\text { kunstriffen }\end{array}$} & $\begin{array}{l}\text { Passieve visserij } \\
\text { schaaldieren } \\
\text { (krabben en } \\
\text { kreeften): kooien op } \\
\text { zeebodem }\end{array}$ & $\begin{array}{l}\text { Mogelijke fysieke } \\
\text { verstoring rif door } \\
\text { gebruik en verlies van } \\
\text { vistuig }\end{array}$ & $\begin{array}{l}\text { Wellicht voordeel } \\
\text { door het } \\
\text { wegvangen van } \\
\text { krabben en } \\
\text { kreeften die jonge } \\
\text { oesters kunnen } \\
\text { prederen. }\end{array}$ & $\begin{array}{l}\text { Geen synergie. Vistuig kan } \\
\text { oesterriffen verstoren, maar } \\
\text { impact zal niet groot zijn. } \\
\text { Voor doelsoorten passieve } \\
\text { visserij (kreeften/krabben): } \\
\text { zal mogelijk extra draagkracht } \\
\text { van oesterriffen door extra } \\
\text { schuilplaatsen en extra } \\
\text { voedselaanbod opleveren, en } \\
\text { door wegvangen van deze } \\
\text { predatoren op jonge oesters } \\
\text { de predatiedruk wellicht } \\
\text { afnemen. Hoe deze balans in } \\
\text { predatierisico op jonge } \\
\text { oesters netto uitpakt is vooraf } \\
\text { moeilijk te bepalen. }\end{array}$ \\
\hline & $\begin{array}{l}\text { Passieve visserij vis: } \\
\text { kooien op } \\
\text { zeebodem, } \\
\text { lijnvisserij }\end{array}$ & $\begin{array}{l}\text { Mogelijke fysieke } \\
\text { verstoring rif door } \\
\text { gebruik en verlies } \\
\text { vistuig }\end{array}$ & Geen voordelen. & $\begin{array}{l}\text { Geen synergie. Vistuig kan } \\
\text { oesterriffen verstoren, maar } \\
\text { impact zal niet groot zijn. } \\
\text { Andersom kunnen platte } \\
\text { oesterriffen wel een voordeel } \\
\text { voor passieve visserij } \\
\text { opleveren door extra } \\
\text { draagkracht ten gevolge van } \\
\text { extra schuilplaatsen en extra } \\
\text { voedselaanbod voor vissen. }\end{array}$ \\
\hline & $\begin{array}{l}\text { Drijvende kweek } \\
\text { zeewier }\end{array}$ & $\begin{array}{l}\text { Bij kweek op hele grote } \\
\text { schaal zou een } \\
\text { draagkracht-probleem } \\
\text { door onttrekking van } \\
\text { nutriënten kunnen } \\
\text { optreden (maar lijkt niet } \\
\text { heel waarschijnlijk) }\end{array}$ & $\begin{array}{l}\text { Mogelijk extra } \\
\text { voedseltoevoer } \\
\text { naar bodem, } \\
\text { afhankelijk van } \\
\text { schaal. }\end{array}$ & $\begin{array}{l}\text { Mogelijk synergie door extra } \\
\text { voedselaanbod voor oesters. } \\
\text { Kan helpen om oesterherstel } \\
\text { te vergroten. }\end{array}$ \\
\hline & $\begin{array}{l}\text { Drijvende kweek } \\
\text { schelpdieren } \\
\text { (mossel, platte } \\
\text { oester) }\end{array}$ & $\begin{array}{l}\text { Bij kweek op grote } \\
\text { schaal zou een } \\
\text { draagkracht- probleem } \\
\text { door concurrentie om } \\
\text { voedsel tussen platte } \\
\text { oesterriffen en } \\
\text { schelpdiercultures } \\
\text { kunnen optreden. } \\
\text { Verder zou te veel } \\
\text { materiaal dat bezinkt } \\
\text { ook negatieve effecten } \\
\text { kunnen hebben op de } \\
\text { platte oesters. }\end{array}$ & $\begin{array}{l}\text { Mogelijk extra } \\
\text { nutriëntentoevoer } \\
\text { door neerdalen van } \\
\text { excretie (faeces, } \\
\text { geen direct } \\
\text { voedsel) en extra } \\
\text { reproductie (meer } \\
\text { aanbod schelpdier- } \\
\text { recruits op bodem), } \\
\text { mogelijk vestiging } \\
\text { zelf ook extra } \\
\text { gefaciliteerd door } \\
\text { schelpen die op de } \\
\text { bodem neerkomen. }\end{array}$ & $\begin{array}{l}\text { Mogelijk synergie door extra } \\
\text { voedselaanbod voor oesters, } \\
\text { extra aanvoer van oester- } \\
\text { recruits (bij kweek van platte } \\
\text { oester in waterkolom) en } \\
\text { schelpen die op de bodem } \\
\text { terecht komen kunnen } \\
\text { vestiging van platte oesters } \\
\text { bevorderen. Dit alles kan } \\
\text { helpen om oesterherstel te } \\
\text { vergroten. }\end{array}$ \\
\hline & $\begin{array}{l}\text { Duurzame energie } \\
\text { (zonnepanelen, } \\
\text { getijdegeneratoren } \\
\text { golf-generatoren) }\end{array}$ & $\begin{array}{l}\text { Geen nadelen. Wel kan } \\
\text { zeer grootschalig } \\
\text { gebruik van } \\
\text { zonnepanelen door } \\
\text { schaduwwerking } \\
\text { negatieve effecten op } \\
\text { primaire productie } \\
\text { hebben }\end{array}$ & $\begin{array}{l}\text { Biofouling op } \\
\text { structuren zal } \\
\text { bijdragen aan een } \\
\text { verhoogde } \\
\text { depositie van } \\
\text { detritus en } \\
\text { organismen }\end{array}$ & Geen synergie \\
\hline \multicolumn{5}{|l|}{$\begin{array}{l}\text { "Europese } \\
\text { zeekreeft" }\end{array}$} \\
\hline \multirow[t]{4}{*}{$\begin{array}{l}\text { Kreeftenherstel: } \\
\text { kunstriffen op } \\
\text { bodem als } \\
\text { schuilplek en } \\
\text { voedselbron }\end{array}$} & $\begin{array}{l}\text { Passieve visserij } \\
\text { schaaldieren } * \\
\text { (krabben en } \\
\text { kreeften): kooien op } \\
\text { zeebodem }\end{array}$ & $\begin{array}{l}\text { Vangst van de te } \\
\text { herstellen soort }\end{array}$ & Geen voordelen & $\begin{array}{l}\text { Geen synergie. Voor Europese } \\
\text { zeekreeften: verstoort } \\
\text { populatieherstel door } \\
\text { wegvangen van dieren. }\end{array}$ \\
\hline & $\begin{array}{l}\text { Passieve visserij vis: } \\
\text { kooien op zeebodem }\end{array}$ & $\begin{array}{l}\text { (Bij)vangst van de te } \\
\text { herstellen soort }\end{array}$ & Geen voordelen & $\begin{array}{l}\text { Geen synergie. Voor Europese } \\
\text { zeekreeften: verstoort herstel } \\
\text { door (bij)vangst van dieren. }\end{array}$ \\
\hline & $\begin{array}{l}\text { Drijvende kweek } \\
\text { zeewier }\end{array}$ & Geen nadelen & Geen voordelen. & Geen synergie. \\
\hline & $\begin{array}{l}\text { Drijvende kweek } \\
\text { schelpdieren } \\
\text { (mossel, oester) }\end{array}$ & Geen nadelen & $\begin{array}{l}\text { Mogelijk extra } \\
\text { voedseltoevoer } \\
\text { naar bodem door } \\
\text { excretie (indirect } \\
\text { via lokale } \\
\text { verhoging } \\
\text { secundaire } \\
\text { productie) en } \\
\text { vooral epifauna als } \\
\text { direct voedsel voor } \\
\text { deze predatoren en } \\
\text { aaseters }\end{array}$ & $\begin{array}{l}\text { Mogelijk synergie. Voor } \\
\text { Europese zeekreeften: } \\
\text { mogelijk positieve impact } \\
\text { door extra voedselaanbod. } \\
\text { Kan helpen om natuurherstel } \\
\text { te vergroten. }\end{array}$ \\
\hline
\end{tabular}


Duurzame energie
Geen nadelen
Biofouling op

structuren zal

bijdragen aan een

verhoogde

depositie van

detritus en
Mogelijk synergie. Met name de type van verankering aan

de bodem van deze structuren

in combinatie met epifauna en

lokale productie geeft

mogelijkheden voor synergie.

* In België is ook interesse in een passieve visserij op wulken, wellicht kan deze ook in windmolenparken worden toegepast. Verder dan een losse melding van een reder gaat dit niet, maar misschien liggen hier wel kansen op synergie (dit afhankelijk van de in te zetten vangsttechniek uiteraard).

Naast interacties tussen natuurherstel en medegebruik in WEG Borssele, zijn er wellicht ook kansen voor synergie tussen verschillende vormen van medegebruik in dezelfde kavels. Of vormen van medegebruik die juist niet samen gaan in dezelfde kavels. We beschouwen hier alleen de biologische aspecten hiervan, niet de logistieke of bedrijfsmatige beperkingen of voordelen die hiermee gepaard kunnen gaan.

Zo zullen drijvende kweek van schelpdieren en passieve visserij goed samen kunnen gaan. Het grotere oppervlak aan hardsubstraathabitat en daarmee geassocieerde epifauna zal gunstig uitpakken voor de lokale productie van schaaldieren (krabben en kreeften) en vissoorten als kabeljauw. Dit zou ook op kunnen gaan voor de combinatie drijvende zeewierkweek en passieve visserij, maar hier lijkt de synergie minder groot omdat er wellicht minder epifauna tussen het zeewier leeft dan er op en nabij hard substraat riffen voorkomt.

Ook energieopwekking met zonnepanelen en passieve visserij zouden goed samen kunnen gaan omdat ook hier het areaal aan hardsubstraathabitat via de aangebrachte structuren en geassocieerde epifauna een gunstig effect op de lokale productie van schaaldieren en vissoorten als kabeljauw kan hebben.

\subsection{Kabeljauw}

\subsubsection{Effect van kunstriffen op samenstelling visfauna}

De hardsubstraathabitats in offshorewindparken rondom windpalen, zowel de erosiebeschermende stortsteen rondom de funderingen (zogenaamde 'scour bed') als de palen zelf, trekken veel vissen aan, en fungeren derhalve als kunstriffen (Reubens et al. 2013, van Hal et al. 2012). Voor de windparken in de Nederlandse en Belgische Noordzee zien we dat een deel van de vissoorten meer voorkomt bij de hardsubstraathabitats in offshorewindparken, met name kabeljauw, steenbolk en zeedonderpad (Reubens et al. 2013, van Hal et al. 2012, van Hal et al. 2017). Deze foerageren op epifauna dat op de harde substraten groeit, of hiermee geassocieerd is, zoals bleek uit dieetstudies van kabeljauw en steenbolk, die benutting tenminste op een korte termijn aantonen (Reubens et al. 2013, de Troch et al. 2013). Recentelijk is met stabiele isotopenanalyses ook aangetoond dat hardsubstraathabitats in offshorewindparken ook voor langere termijnen (tot 6 maanden) worden benut door tenminste kabeljauw, steenbolk en zeedonderpad, terwijl dit voor horsmakreel en makreel niet opging (Mavraki et al. 2020, Mavraki et al. 2021).

Er zijn twee hypotheses voor het voorkomen van deze hogere visdichtheden rond kunstriffen (Brickhill et al. 2005):

1) Aantrekkingskracht: Vissen uit de omgeving worden aangetrokken door kunstriffen, bijvoorbeeld door de grotere habitatcomplexiteit die betere bescherming biedt tegen predatoren of luwere plaatsen biedt met minder stroming. Dit resulteert erin dat vissen zich hier tijdelijk concentreren, maar dat de algehele productie van vis hier niet direct door wordt veranderd ('attraction hypothesis').

2) Productie: Vissen benutten de kunstriffen om te foerageren op voedsel dat op deze kunstriffen groeit waardoor de lokale draagkracht voor deze vissoorten groter wordt ('production hypothesis').

Deze hypotheses hoeven elkaar niet uit te sluiten en kunnen voor sommige vissoorten tegelijkertijd opgaan (Brickhill et al 2005). De attraction-production-hypothese en hoe deze voor de verschillende 
vissoorten uitpakt is van belang voor het beheer van offshorewindparken en vraagstukken rond medegebruik hiervan.

De 'production-hypothese' gaat vooral op voor benthische soorten als zeedonderpad en benthopelagische soorten als kabeljauw en steenbolk, terwijl voor pelagische soorten als horsmakreel en makreel waarschijnlijk vooral de 'attraction-hypothese' opgaat (Mavraki et al. 2021).

De aanleg van kunstriffen in kavel II in Borssele kan leiden tot een vergroting van de lokale draagkracht en daarmee verhoging van de lokale productie van benthopelagische vissoorten als kabeljauw en steenbolk. Voor het gebruik van hardsubstraathabitats rond de palen van windturbines in Nederlandse en Belgische windmolenparken is het afgelopen decennium relatief veel onderzoek gedaan (Winter et al. 2010, Reubens et al 2013a, -2013b, 2013c, 2014, van de Knaap et al. 2021a, 2021b). De vier kunstriffen in kavel II, op basis van betonnen pijpen met verschillende diameters met en zonder scour bed, zoals die nu binnen Natuurinclusief-boouwenprojecten in kavel II zijn aangelegd, zullen naar verwachting ook lokale benutting door kabeljauw faciliteren. Zoals ook bij op de bodem geplaatste reef-balls nabij Belgische windparken het geval is (van der Knaap et al. 2021).

Gedurende februari 2021-december 2022 wordt hier een zenderonderzoek met kabeljauw uitgevoerd door Wageningen Marine Research in opdracht van Ørsted (Figuur 3).

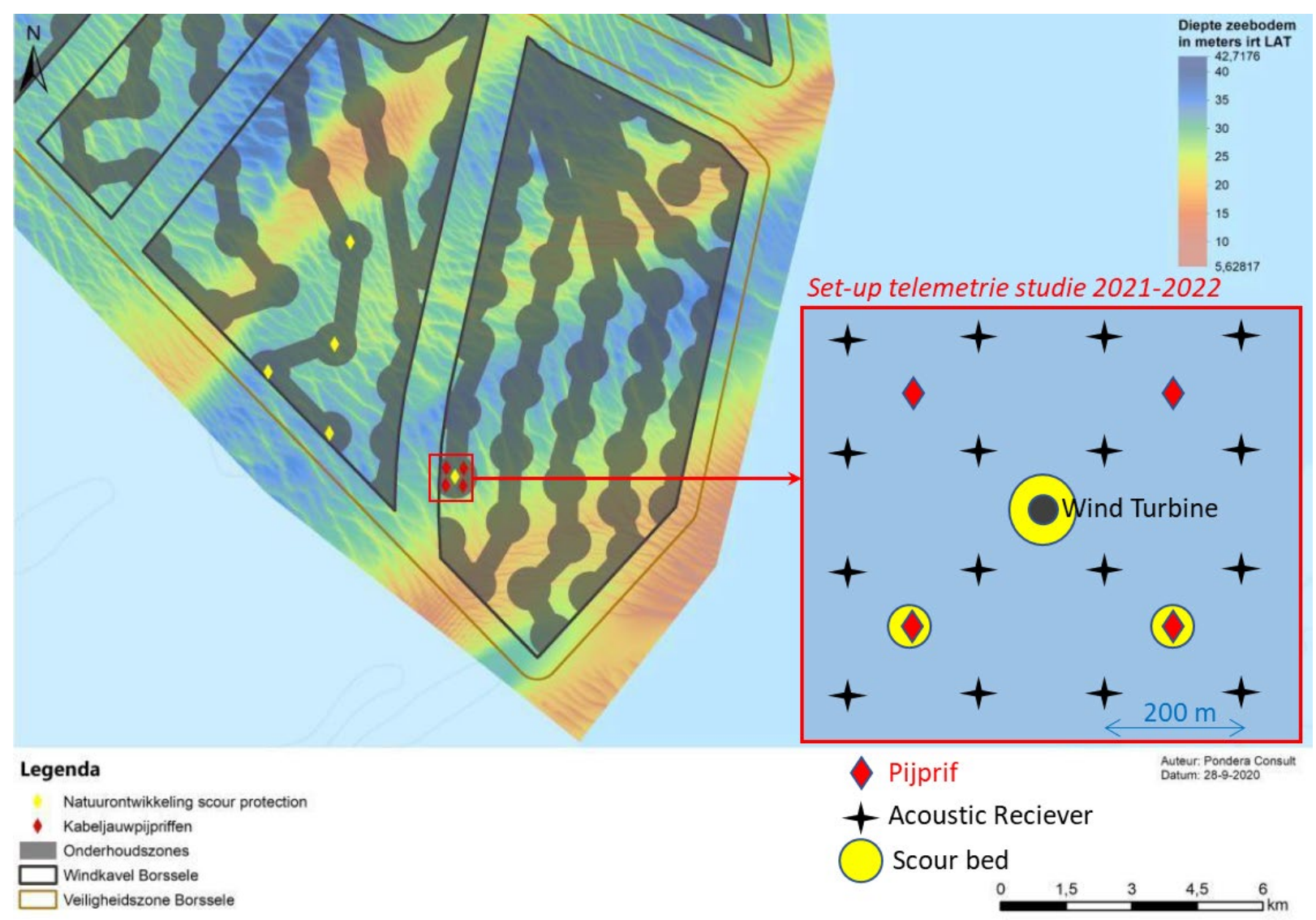

Figuur 3. Opzet van het telemetrie-onderzoek gedurende 2021-2022 bij de 4 pijpriffen voor kabeljauw (rode ruiten) in kavel II. Scour protection (gele cirkels) rond de twee zuidelijke kunstriffen en de centraal gelegen windturbine zijn weergegeven. De twee noordelijke pijpriffen hebben geen 'scour protection'. De zwarte kruizen geven het grid van 16 detectiestations (4x4) weer op 200m onderlinge afstand, waarbinnen bewegingen van met akoestische zenders uitgeruste kabeljauw, en Europese zeekreeft, in 3D kan worden gemeten (figuur op basis van Pondera Consult 2020, aangepast met invoeging van telemetrie set-up).

\subsubsection{Gedrag en bewegingspatronen binnen windparken}

Om te bepalen in hoeverre medegebruik (passieve visserij) en natuurherstel elkaar in de weg zitten of elkaar kansen bieden, is inzicht nodig in het ruimtelijk gebruik van windparken en kunstriffen door kabeljauw. Hiervoor is het van belang om te bepalen op welke wijze en schaal (in tijd en ruimte) deze 
kunstriffen worden benut door individuele vissen en ook door welke potentiële factoren dit verstoord zou kunnen worden. Vragen zijn: welke levensstadia maken gebruik van deze habitats, wat is hun verblijftijd bij de harde structuren, welke variatie in gedrag tussen individuen binnen de dezelfde soort kunnen worden waargenomen, welke potentieel verstorende factoren treden op? Hoe snel worden nieuwe structuren gekoloniseerd? En, op welke schaal bewegen vissen zich in een windpark?

\section{Juveniele kabeljauw}

Onderzoek aan kabeljauw in Belgische en Nederlandse offshorewindparken heeft laten zien dat er met name juveniele kabeljauw (tot grofweg $60 \mathrm{~cm}$ in lengte) in de windparken wordt gevangen. Zowel in pas aangelegde windparken (bijvoorbeeld in OWEZ zie Winter et al. 2010), maar ook in al langer bestaande windparken (bv van der Knaap et al. 2021a, 2021b). Daardoor is het zeer waarschijnlijk dat kolonisatie van deze nieuwe habitats door jonge kabeljauw snel kan verlopen.

Zenderonderzoek laat zien dat tenminste een deel van de juveniele kabeljauw zeer honkvast kan zijn, en langdurig (tot jaarrond) rondom een enkele windmolenpaal kan verblijven (zie Figuur 4, Winter et al. 2010, Reubens et al. 2013). Er is veel individuele variatie in gedragspatronen, waarbij er een continuüm van zeer lokale sterk plaatsgebonden kabeljauwen (schaal van benutting tot honderden meters rondom een enkele paal), tot van een paal naar een nabij gelegen paal verkassende kabeljauwen tot meer mobiele individuen die zich op grotere schaal bewegen. Van deze laatste groep is de ruimtelijke schaalgrootte waarop deze bewegingen plaats vinden minder bekend, omdat de netwerken aan detectiestations hier ontoereikend voor zijn.

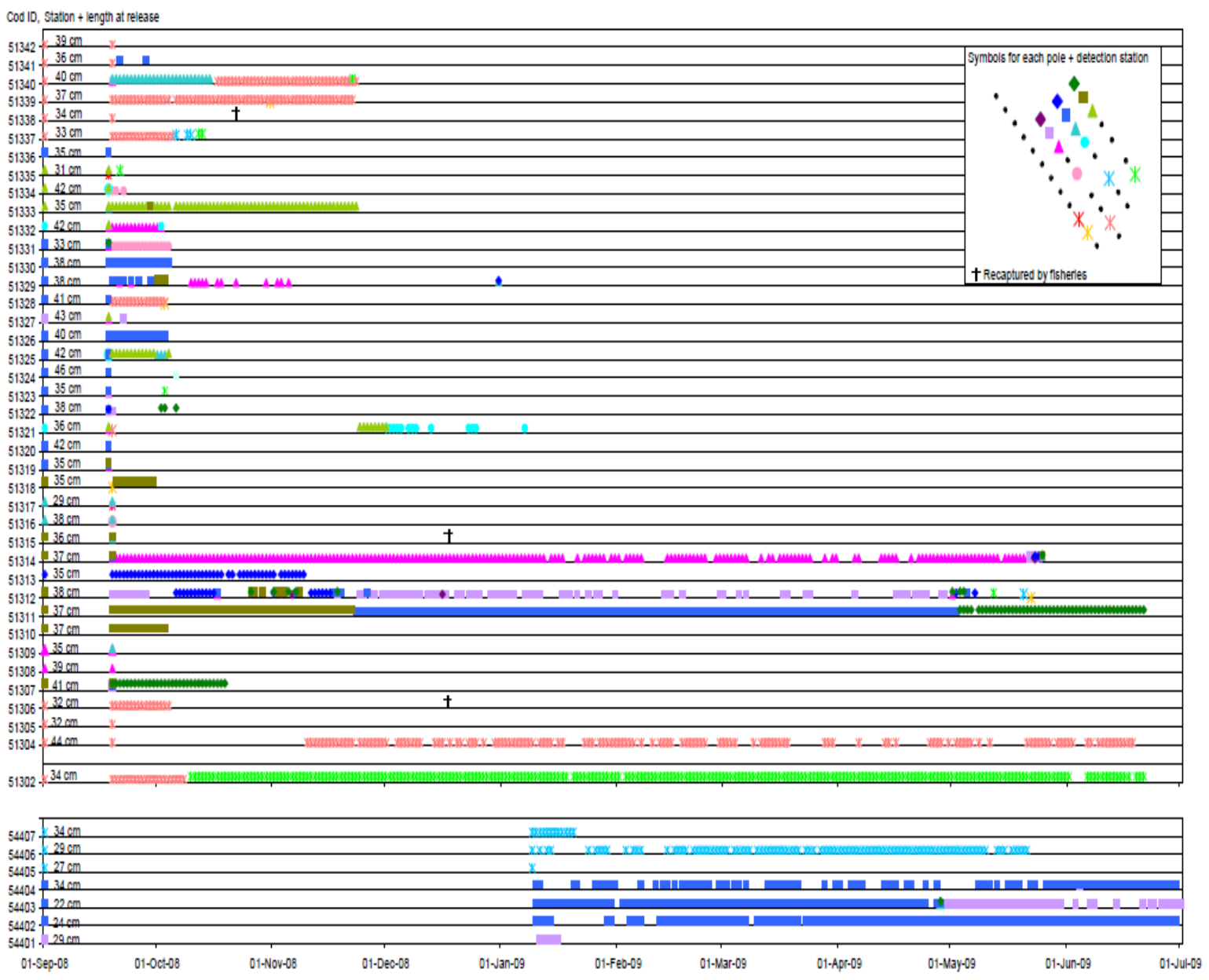

Figuur 4. Individuele bewegingspatronen van gezenderde kabeljauwen in offshorewindpark OWEZ gedurende september 2008 - juli 2009. Elk kleur-symbool geeft een windmolenpaal met een detectiestation weer (zie legenda rechtsboven), uit Winter et al. (2010).

In onderzoek met gezenderde kabeljauwen in Belgische windparken is ook waargenomen dat kabeljauwen vanaf monopiles ook nabij gelegen kunstriffen (reef-balls) gebruikten (zie Figuur 5, van der Knaap et al. 2021). Van de OWEZ-studie en de Belgische studies (zie Figuur 6) zijn daarnaast ook kabeljauwen buiten het offshore-windpark terug gevangen door visserijen (Winter et al. 2010) of 
opgedoken op andere detectiestations in de monding van de Westerschelde of het Belgische deel van de Noordzee (ongepubliceerde data VLIZ).

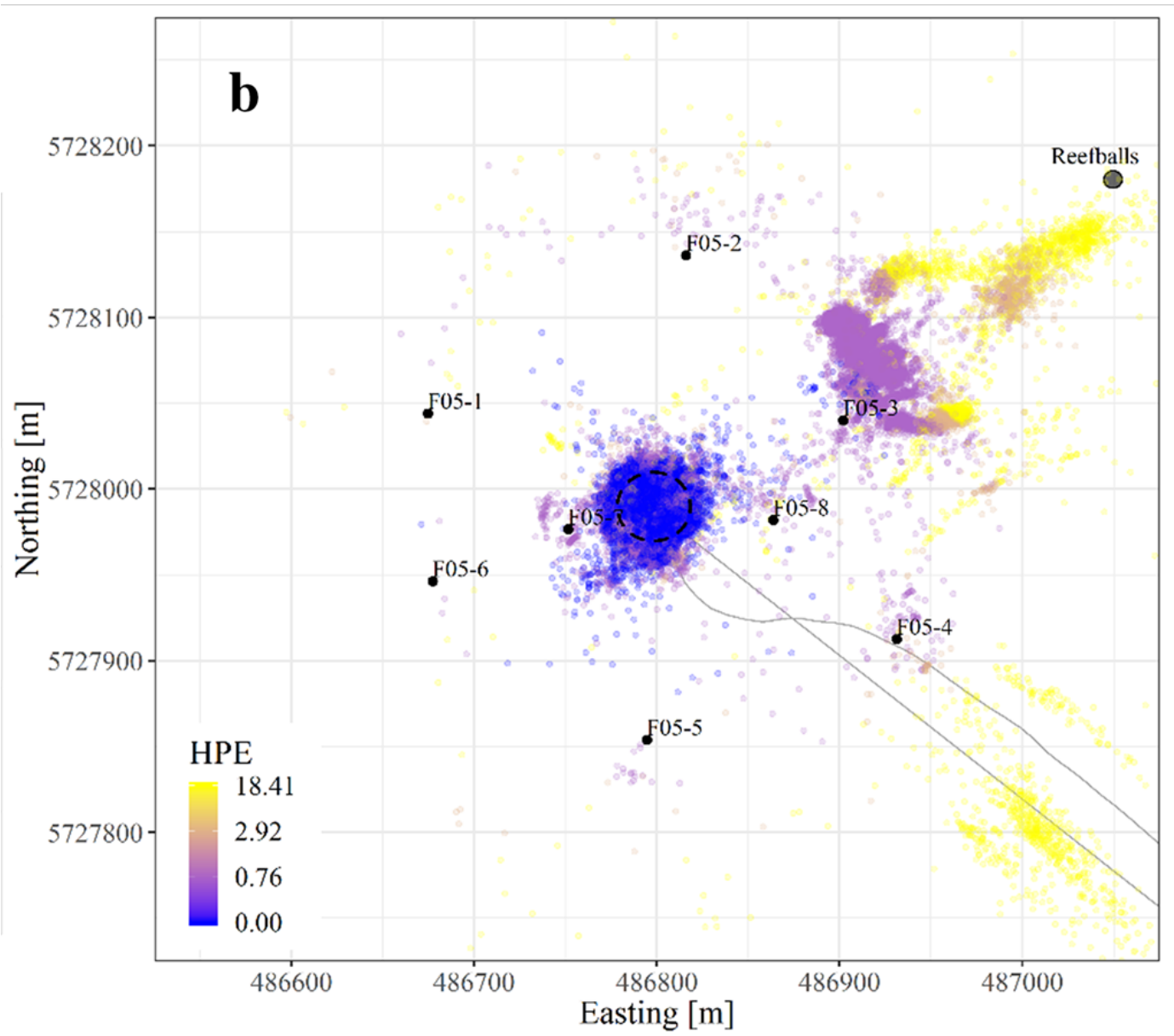

Figuur 5. Habitatgebruik van gezenderde kabeljauwen rondom een windturbine en nabij gelegen reef balls (rechtsboven) in het noordwestelijke deel van het Belgische offshorewindpark Belwind. Mt name het scourbed direct rond de monopile en in de richting naar de reefballs werden het meest intensief. De positionering binnen de ring ontvangers is nauwkeuriger dan daarbuiten (zoals de Horizontal Positioning Error HPE aangeeft), waardoor er in werkelijkheid meer posities bij de reefballs zullen liggen dan alleen in de richting hiernaar toe (van der Knaap et al. 2021).

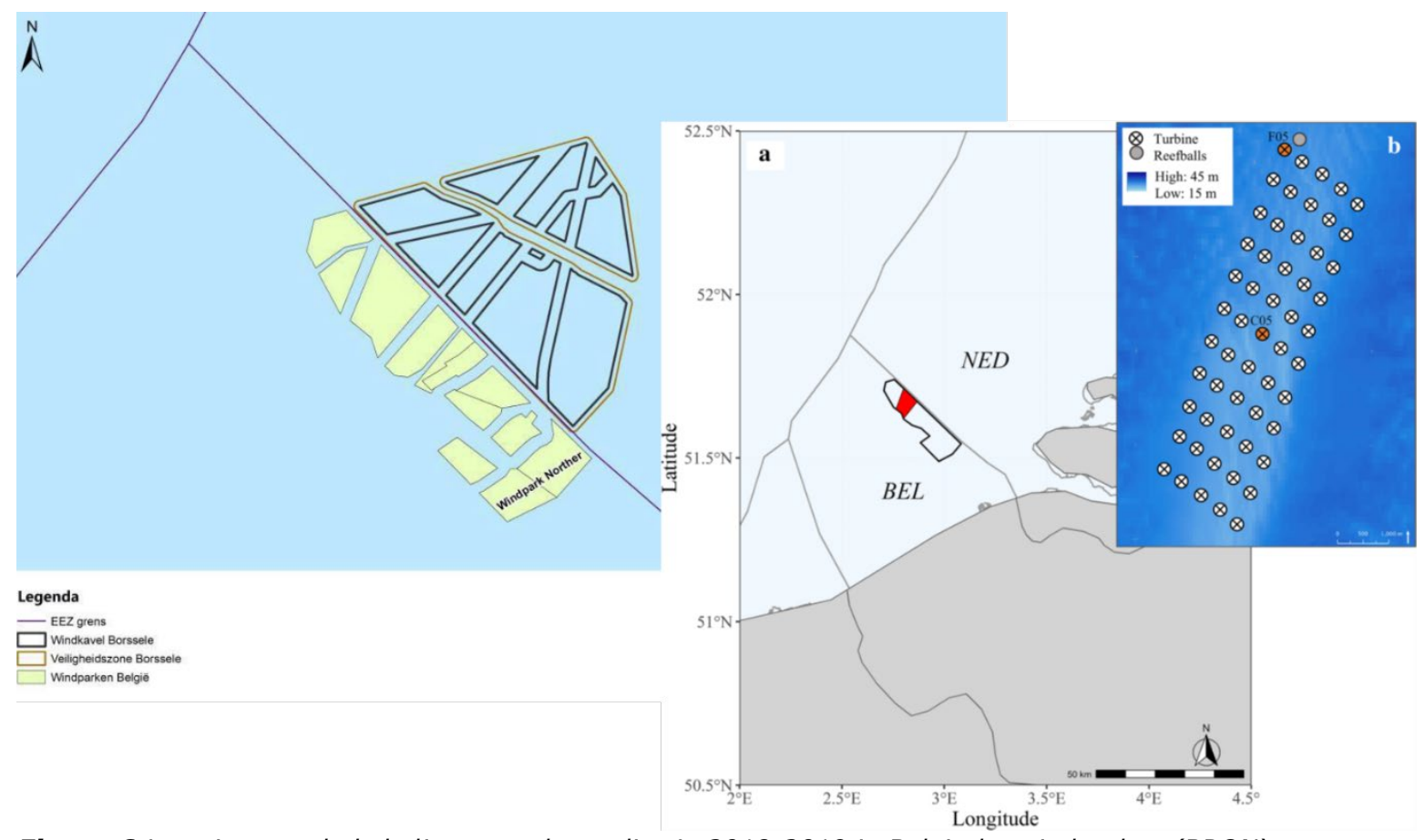

Figuur 6 Locaties van de kabeljauw zenderstudies in 2018-2019 in Belgische windparken (BRON). 
Ook is er een seizoenscomponent in de bewegingen van juveniele kabeljauwen waar te nemen: met een hogere presentie in het windmolenpark in het zomerhalfjaar en een geringere presentie in het winterhalfjaar. Zo zijn er gezenderde kabeljauwen die 's zomers de Belgische offshorewindparken benutten en in het winterhalfjaar meer inshore bij de monding van de Westerschelde zijn gedetecteerd (ongepubliceerde data VLIZ). Ook in OWEZ bij IJmuiden is waargenomen dat gezenderde kabeljauwen in het najaar een grotere kans op verkassen lieten zien.

\section{Volwassen kabelkauw}

Volwassen kabeljauwen lijken de windparken in veel mindere mate te benutten ( van der Knaap et al. 2021a, 2021b). Of dit gerelateerd is aan het wegtrekken naar paaigebieden of dat het gerelateerd is aan een veranderende voedselpreferentie gedurende het opgroeien van juveniele naar volwassen kabeljauw is niet goed bekend.

\subsubsection{Mogelijke effecten van passieve visserij}

Passieve visserij waarbij kabeljauwen worden (bij)gevangen kunnen het telemetrie-experiment beïnvloeden doordat er gezenderde kabeljauwen worden onttrokken aan het experiment, waardoor het gebruik van de nieuwe typen pijpriffen met en zonder scour protection niet goed onderzocht kan worden en hier geen kennis over wordt gegenereerd.

De kans op deze ongewenste vangst van gezenderde kabeljauw is het grootst met visserijmethoden die zijn gericht op benthische vissen, zoals met lijnvisserij of hengel nabij de bodem, of staand want. Maar ook in beaasde kooien kunnen jonge kabeljauwen worden bijgevangen, zoals bijvoorbeeld in de Noorse fjorden wordt toegepast (Winter et al. 2010), maar deze vangstmethode lijkt minder risicovol voor bijvangst op kabeljauw. Wat de kans op bijvangst is van jonge kabeljauw in beaasde kreeftenkorven is minder goed bekend, maar enige bijvangst kan wel optreden. Wat de effecten zijn van geluid die met de bedrijfsvoering van passieve visserij gepaard gaat, is niet goed bekend.

Zelfs als gevangen gezenderde kabeljauw, die ook aan een uitwendig merk herkenbaar zijn (zogenaamde Floy-tag) weer worden teruggezet, is er onder meer door de kans op barotrauma door te snel naar de oppervlakte halen van de gevangen kabeljauw, een reëel risico dat deze kabeljauwen verloren zijn voor het onderzoek.

Naast de impact van vangst van gezenderde vissen kan ook het gedrag van de vissen door activiteiten en daarmee gepaard gaande verstorende factoren als geluid optreden. Er is nog weinig bekend over de invloed van geluid op gedrag van kabeljauw. Het operationele geluid van windmolenturbines in windparken lijkt geen grote invloed op kabeljauw te hebben (Winter et al. 2010). Seismische surveys gaven ook op afstand wel indicaties voor veranderingen in gedrag, te weten minder activiteit en grotere kans op wegtrekken (van der Knaap et al. 2021).

\subsubsection{Mogelijke kansen van passieve visserij}

Alle harde structuren die aangebracht worden in het offshorewindpark zullen de lokale productie van benthische en benthopelagische vis zoals kabeljauw potentieel kunnen verhogen (productiehypothese) en daardoor een uitstraaleffect hebben op omliggende kavels op kleinere schaal, en visserijen en populatieomvang op grotere schaal. De relatie lokale productie en uitstraaleffect op grotere schaal zou verder verkend kunnen worden met populatie-modellen.

\subsubsection{Voorstel visserijvrije zone}

\section{Optie 1:}

Wanneer we alleen rekening hoeven te houden met de mogelijke effecten op het experiment met de natuurinclusiefbouwenstructuren in het deel van kavel II waar de structuren staan, komen we tot het volgende. Aangezien de individuele kabeljauwen die honkvast zijn, zich slechts over geringe afstanden 
rondom de turbinepalen bewegen (100en meters), en van hieruit wellicht wel bewegingen tussen omliggende rifstructuren ondernemen, zoals bij de reef balls nabij het Belgische windpark is waargenomen en omdat er voor de individuen die verkassen naar andere windturbines, relatief weinig terugkeergedrag naar de initiële turbine (dan wel kunstrif-locatie) plaats vindt, lijkt het voor het goed verlopen van het telemetrieonderzoek aan kabeljauw veilig om naast het grid met 16 detectiestations ook de ring met turbines die daar omheen liggen te vrijwaren van visserij. Een grotere visserijvrije zone om het studiegebied leggen geeft naar verwachting maar een zeer geringe beïnvloeding van het zender-experiment met kabeljauw, omdat kabeljauwen die buiten het studiegebied uitwaaieren een steeds kleinere kans hebben om nog bij te dragen aan het onderzoek. Voor kabeljauw zou een (tijdelijke) visserijvrije zone tot aan 1,5 km rondom de ring van windturbines die om de 4 kunstriffen liggen naar verwachting beïnvloeding van het onderzoek in grote mate voorkomen (zie indicatie met rode lijn in figuur 7.

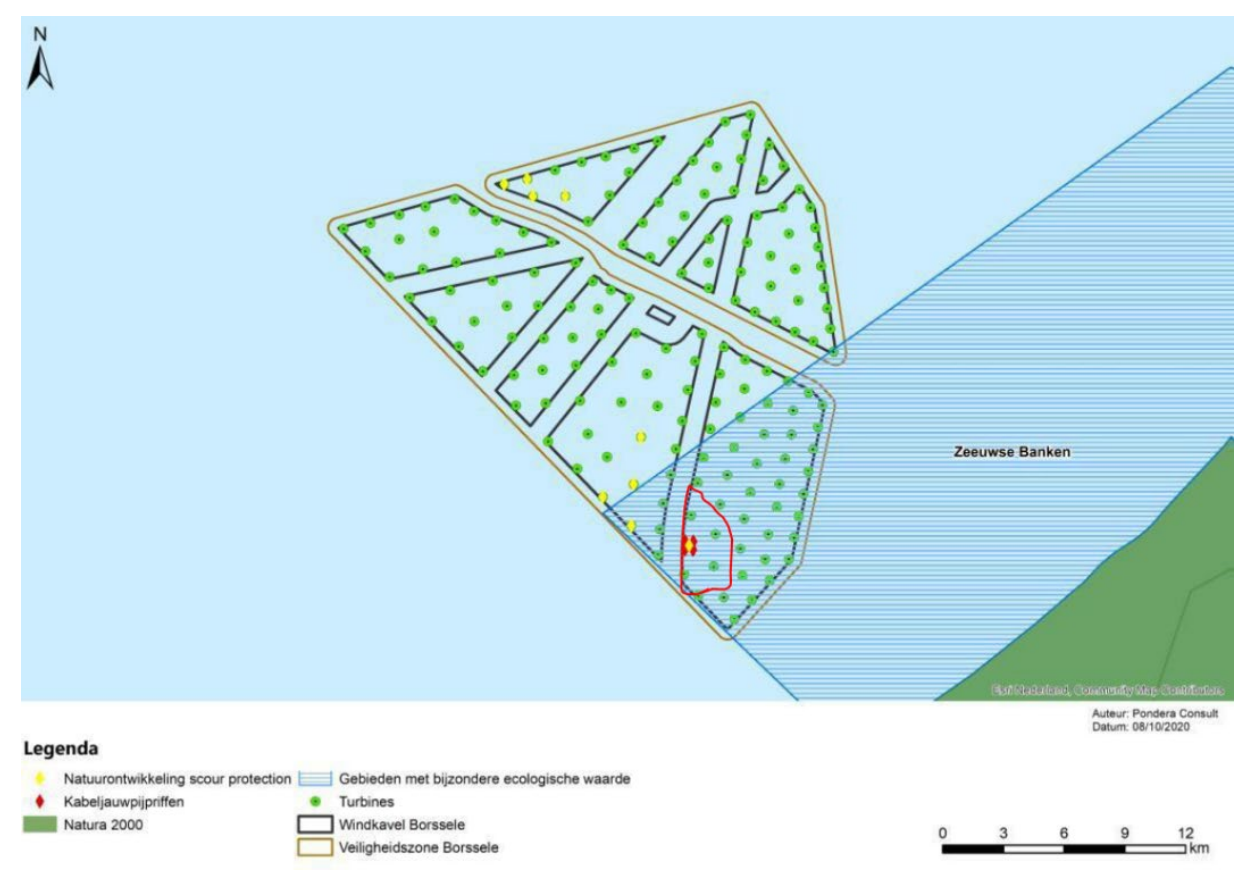

Figuur 7. Voorstel visserij vrije kabeljauw-zone (rood): een ring van $1.5 \mathrm{~km}$ rondom de ring van windturbines die om de kunstriffen liggen om met name de natuurinclusiefbouwen locaties en het onderzoek naar hoe kabeljauw deze nieuwe hardsubtraathabitats benut te vrijwaren van effecten van passieve visserij op het zenderonderzoek.

\section{Optie 2:}

Wanneer het natuurinclusiefbouwenproject wordt gezien als - een eerste startpunt - voor het willen bevorderen van kabeljauw in heel kavel II dan wel in beide kavels (I + II) van vergunninghouder $\emptyset$ rsted, dan zou deze niet gecombineerd moeten worden met passieve visserij op vis (lijnvisserij, staand want). Gezien de beperkte home ranges en honkvastheid van veel juveniele kabeljauw, en het de indicaties dat voor kabeljauw de 'production hypothesis' op gaat (benutten aan

hardsubstraathabitat gerelateerd voedsel voor langere tijd, Mavraki et al. 2021), zal het toestaan van passieve visserij in kavels waar ook beoogd wordt de kabeljauw te herstellen, leiden tot snellere lokale uitputting van de kabeljauwstand. Hiermee zal de extra draagkracht van de natuurinclusiefbouwen hardsubstraat-habitats niet worden gebruikt. Wellicht is het effect zelfs negatief als nieuwe kunstriffen zodanig klein en schaars zijn dat deze alleen als FAD (Fish Attraction Device) fungeren en dan lokale depletie door de mogelijkheid tot gerichtere vangst juist faciliteren. Dit geldt niet alleen voor nieuwe kunstriffen, maar voor alle harde structuren in offshore windparken (en zee). Voor het bijdragen aan een herstel van kabeljauw zal vrijwaring voor visserij in kavels met natuurinclusiefbouwen nodig zijn. Deze gebieden kunnen dan door de toegenomen draagkracht voor juveniele kabeljauw leiden tot een grotere rekrutering van juveniele naar volwassen kabeljauw in omliggende gebieden. Volwassen kabeljauw wordt weinig gezien in de onderzochte windparken, en deze benutten andere habitats. Een windpark kan dan een gunstig 'uitstraaleffect' hebben op de kabeljauwpopulatie op grotere ruimtelijke schaal. 


\subsection{Europese zeekreeft}

\subsubsection{Inleiding}

Europese zeekreeft (Homarus gammarus) is een toppredator, komt voor in de Europese zeeën van het noordelijk deel van Noorwegen tot aan Atlantisch Marokko en de Middellandse Zee en kan naar schatting in ieder geval 72 jaar worden. De planktonische en met name vroeg benthische stadia zijn erg kwetsbaar en vatbaar voor predatie. H. gammarus groeit langzaam, waarbij het minstens vier jaar nodig heeft om onder gunstige omstandigheden volwassen te worden, hoewel over het algemeen wordt aangenomen dat de volwassenheid begint vanaf vijf jaar, afhankelijk van de omgevingsomstandigheden (temperatuur en voedselbeschikbaarheid). Reproductie vindt plaats in een cyclus van twee tot drie jaar. De eieren worden ongeveer een jaar op de pleopoden gehouden totdat ze uitkomen. De grootte van het ei is bij de Europese zeekreeft relatief groot, de legselgroottes relatief klein (20.000 tot 40.000 maximaal eieren per keer) en de broedperiode lang in vergelijking met andere mariene tienpotigen van vergelijkbare grootte. Op zichzelf is de reproductie voldoende om de populaties op een constant niveau te houden (waarschijnlijk mede door de hoge leeftijd). Wereldwijd hebben kreeftenpopulaties echter te maken gehad met aanzienlijke visserijdruk en ineenstorting van de bestanden. Deze herstellen zich nu slechts langzaam in sommige regio's, gedeeltelijk dankzij passend beheer (vrouwtjes met eieren die weer teruggezet worden en het uitzetten van jonge kreeftjes voor de verbetering van de bestanden, Wickins \& Lee, 2002, Prodöhl et al., 2006 , Phillips, 2013, Rozemeijer \& van de Wolfshaar, 2019).

De eerste weken na het uitkomen bestaan uit een pelagische fase die gewoonlijk 10-18 dagen duurt, afhankelijk van de watertemperatuur (drie larvale stadia en één postlarvaal stadium zijn pelagisch) (Wickins \& Lee, 2002, Skerrit, 2014, Figuur 8). Gedurende deze periode ondergaan larven een metamorfose tot een kreeftachtig lichaam bij de vervelling van stadium III tot postlarve. Variabiliteit in productie en overleving van larven en variabiliteit in transport zijn cruciale componenten in de jaarlijkse dynamiek van kreeftenpopulaties. Men schat dat slechts 0,005\% van de jonge kreeften de planktonfase overleeft om de benthische fase te bereiken (Phillips, 2013).

$\mathrm{Na}$ deze verandering naar de postlarvale vorm zwemt de postlarve naar een geschikt substraat (modder, grind of grof zand) om zich te vestigen en een tunnel te graven. De kwetsbare Early Benthic Phase (EBP) is begonnen. In deze fase heeft de EBP een grote behoefte aan schuilplaatsen. Ze voeden zich met zwevend en neerslaand materiaal (algen, detritus) in de stroming door en voor hun tunnel. Bovendien oogsten ze actief de muren van hun tunnel. Hoe productiever de bodem van de zeebodem is (in termen van wormen, vlokreeftjes enz.), hoe minder vaak deze kwetsbare EBP's zich hoeven bloot te stellen aan predatie en stromingen (Lawton \& Lavalli, 1995; Jensen et al., 2000; Wickins \& Lee, 2002).

Door de pelagische fase hebben Europese zeekreeften in principe voldoende mobiliteit om de hele Noordzee te koloniseren hierbij gebruik makend van stepping stones in de vorm van wrakken, harde substraten etc. (Krone en Schröder, 2011). Toch doen zich onverwacht genetische subpopulaties voor, wat impliceert dat op Noordzee-schaal de feitelijke mobiliteit lager is dan potentiële mobiliteit. Blijkbaar is de uitwisseling minder dan geschat op theoretische overwegingen over mobiliteit. 


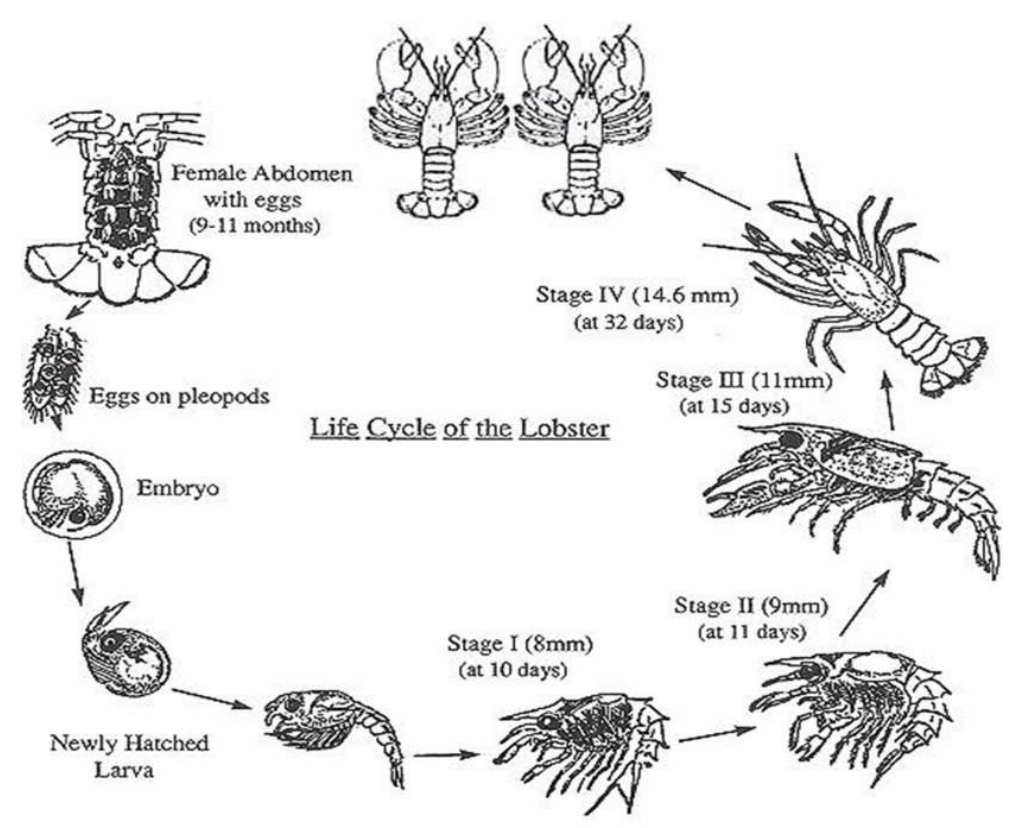

Figuur 8. Levenscyclus van kreeften (Homarus sp.) (bron Skerrit, 2014)

\subsubsection{Effect van kunstriffen op kreeften}

Kunstriffen dienen als schuilplaats voor kreeften. In de vroege benthische fase zijn kreeften afhankelijk van structureel complexe habitats. Jonge Europese zeekreeften tot $40 \mathrm{~mm}$ geven de voorkeur om zich te verschuilen en te voeden in schuilplaatsen. Grotere juvenielen komen tevoorschijn om buiten hun holen te foerageren (Bannister \& Echter, 1991). In deze fase hebben ze beschutting nodig tussen bv. stenen of keien (Galparsoro et al., 2009). Volwassen Europese zeekreeften zijn te vinden in ruimtelijk eenvoudiger habitats. Aangenomen wordt dat de kreeften de voorkeur geven aan habitats op de grens tussen sedimentbodems en rotsachtige bodems (Galparsoro et al., 2009).

\subsubsection{Gedrag en bewegingspatronen}

De mobiliteit van Europese zeekreeft kan worden onderverdeeld in dagelijkse activiteiten en meer migratiebewegingen. Europese zeekreeften zijn overwegend sedentaire dieren met een migratiebereik dat varieert van 0 tot een zeldzame $45 \mathrm{~km}$ (Smith et al., 2001). Ze blijven het liefst op de locaties waar ze zich hebben gevestigd en gaan niet verder dan 3,5 km (Smith et al., 2001). Over het algemeen heeft $H$. gammarus beperkte bewegingen op zijn grondgebied van gemiddeld $<100 \mathrm{~m}$ hemelsbreed over langere periodes (Thorbjørnsen et al., 2018). Er is slechts een klein aantal volwassen individuen waargenomen dat in een seizoen tot $16 \mathrm{~km}$ reist (Jensen et al., 1994, Moland et al. 2011,) tot zelfs tot $45 \mathrm{~km}$ (Smith et al., 2001), vermoedelijk op zoek naar nieuwe territoria. Gemiddeld migreert 4\% naar een ander gebied (Thorbjørnsen et al., 2018). H. gammarus maakt dagelijks korte trektochten vanuit de schuilplaats met een tochtlengte van ca $1 \mathrm{~km}$ en hemelsbreed tot $500 \mathrm{~m}$ (Skerrit et al., 2015, Lees et al., 2018, Figuur 9). Dagelijkse verplaatsingen kunnen variëren tot geaccumuleerde afstanden van ca $5,8 \mathrm{~km}$ per dag. Deze tochten kunnen worden beïnvloed door aard van het substraat (hard, zacht), beschikbaarheid van voedsel, schuilplaatsen en paringspartners en lokale concurrentie voor deze aspecten (Lees et al., 2018, 2020).

Europese zeekreeften zijn vooral 's nachts actief, met de nadruk op de periode net voor of na zonsondergang en net voor en na zonsopgang, hoewel ook overdag activiteit plaatsvindt (Cooper \&. Uzmann, 1980; Van der Meeren, 1997; Walter et al., 1998; Moland et al., 2011a). Skerrit et al. (2015) toonden een nachtelijk actief: passief ritme overdag in de lente en een meer gebalanceerd ritme in de herfst. 's Winters is de Europese zeekreeft ook overdag relatief meer actief (waarschijnlijk licht-gestuurd). 
Cooper \& Uzmann (1980) en Smith et al. (1999, 2000) en Moland et al (2011a) noemden een hoog activiteitspatroon in de zomer en een laag activiteitspatroon in de winter (waarschijnlijk afhankelijk van de temperatuur). Moland et al. (2011a) toonden aan dat de activiteitsniveaus van kreeften vanaf september afnamen en in februari en maart een minimum bereikten. Vanaf april werden de activiteiten weer hervat. Seizoensvariatie in activiteit was gecorreleerd met de watertemperatuur. Skerrit et al. (2015) toonden aan dat Europese zeekreeften actiever waren tijdens de lente (afhankelijk van temperatuur) dan tijdens de herfst (waarschijnlijk afhankelijk van beschikbaarheid van prooien en hoeveelheid licht: kortere dagen).

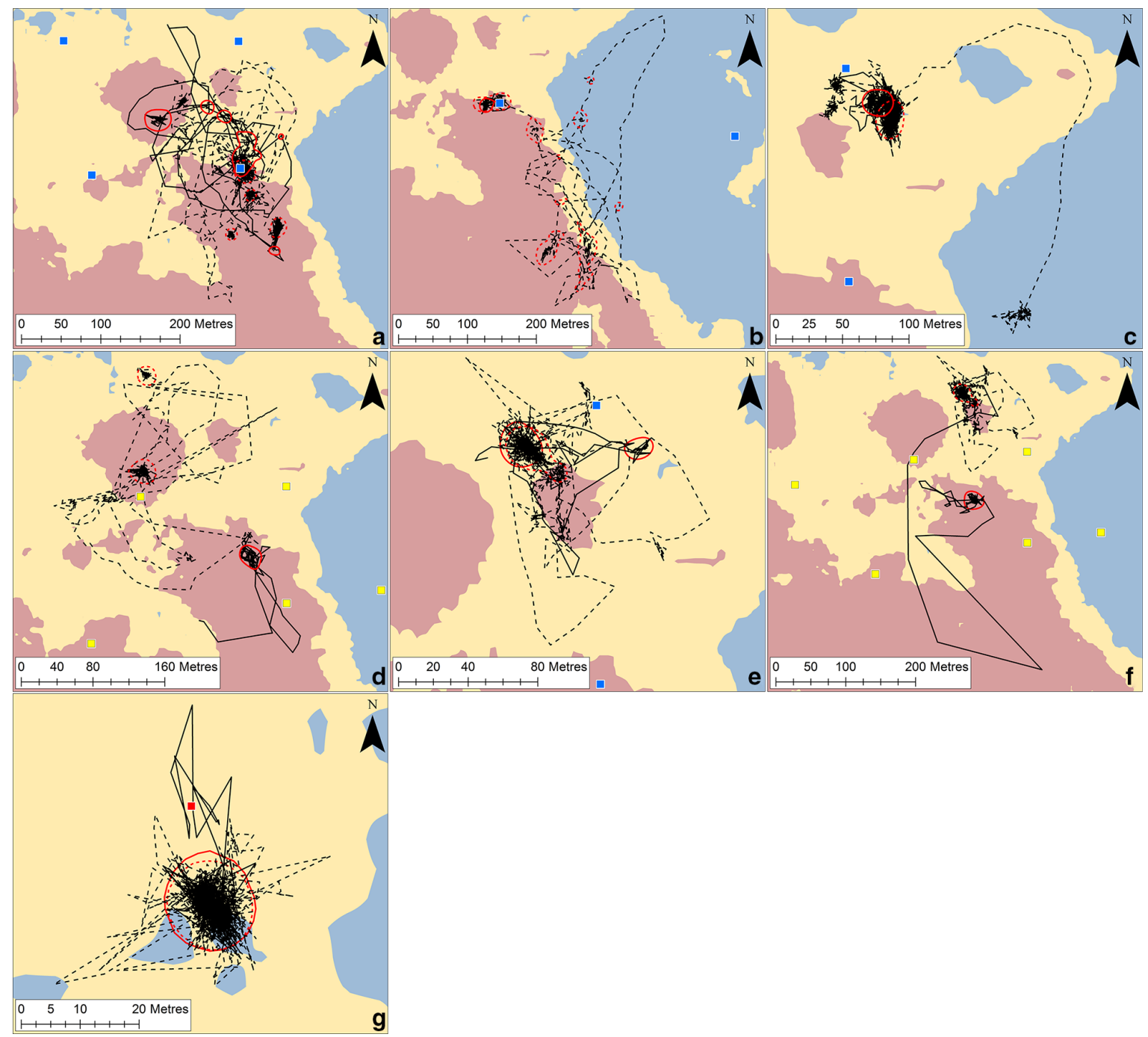

Figuur 9. Beweging in aan- en afwezigheid van vallen. a Kreeft 28179, b kreeft 28187, c kreeft 28189, d kreeft 28192, e kreeft 56815 inzet 2, f kreeft 56815 inzet 3, g kreeft 56816. Pre-trap trajecten $=z w a r t e$ stippellijn, post-trap trajecten = ononderbroken lijn, pre -trap 50\% gebruiksverdeling = rode stippellijn, en post-trap 50\% gebruiksverdeling = rode ononderbroken lijn. Gekleurde vierkanten vertegenwoordigen vallen die zijn ingezet op het moment van nadering (Bron: Lees et al. 2018)

\subsubsection{Territoria}

De grootte van een kreeftenterritorium is afhankelijk van de grootte, het geslacht en de individuele kenmerken van de Europese zeekreeft. Ook de kenmerken van de habitat zelf kunnen van invloed zijn, bv. beschikbaarheid van geschikte holen, gemiddelde hardheid en van voedselbronnen (soort, verspreiding, hoeveelheden) en seizoen (temperatuur, licht) (Cooper \& Uzmann, 1980, Skerrit et al., 2015, Moland et al., 2011b, 2019, Wiig et al., 2013, Lees et al., 2020). De experimentele opzet kan ook van invloed zijn bij de vaststelling van het territorium. Moland et al. (2011b) toonden aan dat er respectievelijk minstens 98 en 259 dagen nodig waren om 50\% en 95\% van het minimale home range 
te bereiken. De totale studie duurde 354 dagen. De meeste onderzoeken naar het territorium duren veel korter. Ook de manier waarop de ruwe data en gegevens worden geïntegreerd en geanalyseerd, kan de schatting van de oppervlakten van de territoria beïnvloeden (vergelijk bv. Moland et al., 2011b versus Wiig et al., 2013, Moland et al., 2019, waarbij de laatste twee grotere oppervlakken inschatten vanwege naar een betere integratiebenadering).

Moland et al. (2019) analyseerden woongebieden met een oppervlakte van 22.733-638.216 $\mathrm{m}^{2}$ voor kreeften in Noorwegen. Het gemiddelde grondgebied was $173.053 \mathrm{~m}^{2}$. De grootte van het territorium correleerde in dit geval met de maand van het jaar (temperatuurgeregelde activiteit). Gebieden kunnen elkaar overlappen of van elkaar gescheiden zijn (Figuur 10). Ze kunnen zich in één samenhangend stuk bevinden of bestaan uit meerdere subgebieden (Wiig et al., 2013, Skerrit et al., 2015. Moland et al., 2011b, 2019, Lees et al., 2018, 2020). Bijv. het langwerpige lichtblauwe gebied in figuur $7 \mathrm{~b}$ heeft een lengte van $\sim 1,2 \mathrm{~km}$ en een breedte van 0,3 km. Het lichtroze territorium in figuur $7 \mathrm{~b}$ strekt zich uit over de langste afstand van $1 \mathrm{~km}$ van rand tot rand (vogelperspectief)

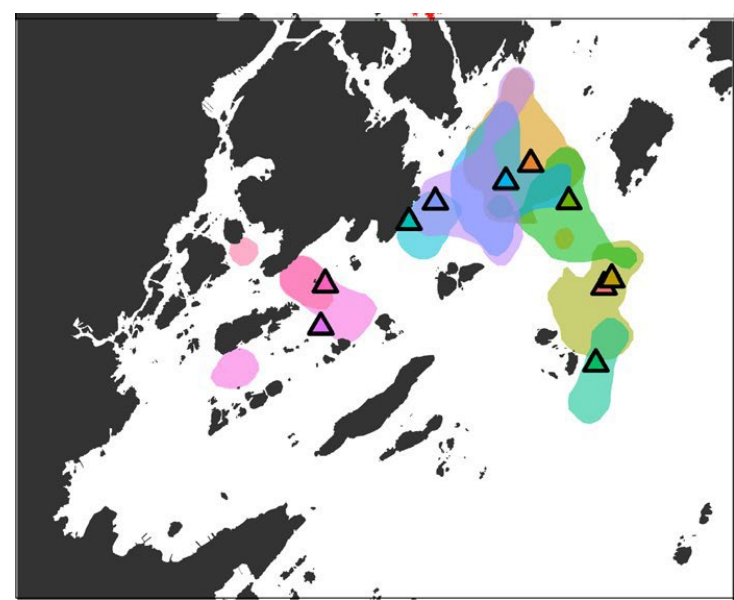

Figuur 10. Voorbeeld van gebiedsgebruik door kreeften in Noorwegen. De gemiddelde home range was $0.173 \mathrm{~km} 2$ (Moland et al., 2019).

\subsubsection{Mogelijke effecten van passieve visserij op de kreeften}

Op basis van de mobiliteit en vangbaarheid zijn er twee scenario's te onderscheiden:

\section{Passieve visserij dicht bij de kunstmatige riffen ( $<100 \mathrm{~m}$ tot $1 \mathrm{~km}$ ):}

Dit zijn afstanden die behoren tot de dagelijkse dynamiek van de zeekreeft. Hierdoor worden waarschijnlijk veel tot alle kreeften gevangen die zich op de kunstmatige riffen bevinden. Passieve visserij waarbij kreeften worden gevangen kunnen het telemetrie experiment beïnvloeden doordat er gezenderde kreeften worden onttrokken aan het experiment, waardoor het gebruik en functioneren van de nieuwe typen pijpriffen met en zonder scour protection als bron van biodiversiteit niet goed onderzocht kan worden en hier geen kennis over wordt gegenereerd.

\section{Aanleggen van een bufferzone met een breedte van $\pm 2 \mathrm{~km}$ rondom de monopile met kunstmatige riffen}

Twee $\mathrm{km}$ is de afstand tussen twee monopiles. Dit is een ruime buffer-afstand waardoor er waarschijnlijk nauwelijks kreeften worden gevangen. Bij een bufferzone van $2 \mathrm{~km}$ biedt onder een bepaalde uitvoeringsvorm wel een toegevoegde waarde:

- Als additionele informatiebron voor het kreeftenonderzoek. Als de vangst van een gezenderde zeekreeft wordt geregistreerd met datum, tijdstip, plek en gebruikt tuig. Dat levert additionele gegevens voor het onderzoek.

- Gevangen en gemerkte zeekreeft zou kunnen worden teruggezet, waarbij er wel kans is op verplaatsing van de zeekreeft naar andere gebieden buiten de meetantennes als de zeekreeft niet op de vangplaats zelf, of met sterke stroming wordt teruggezet waardoor de zeekreeft ook wordt verplaatst. 


\subsubsection{Mogelijke kansen van passieve visserij}

Natuur-inclusief bouwen met kunstriffen of scour-beds met veel schuilplaatsen zal een positief effect hebben op zowel de beschikbaarheid van habitat (met name de benodigde schuilplaatsen: langwerpige tunnels met lengtes variërend tussen de 5 tot $120 \mathrm{~cm}$ ) als het lokale voedselaanbod via epifauna wat als voedsel kan dienen. Wanneer passieve visserij direct wordt uitgevoerd bij de locaties waar ook natuurinclusief wordt gebouwd, is er door de geringe aanvoer van zeekreeft en lage recruitment een reëel gevaar op lokaal, snelle uitputting (depletie) van zeekreeft. Maar als het areaal hard substraat in een deel van het windmolenpark vergroot wordt, kan dit de omvang van de lokale populaties zeekreeft vergroten. En kunnen in aanliggende kavels kreeften worden geoogst zonder dat dit direct effect heeft op de benutting van de natuur-inclusief-bouwen locaties. Hard substraat biedt meer biomassa dan zacht substraat met mogelijk ook een verhoogde productiviteit. De uitstralende werking kan ten goede komen aan de visserij. Ook voor kreeften geldt dat de omvang en talrijkheid van harde structuren bepaald of er inderdaad van toegenomen lokale productie sprake is of dat er alleen aggregatie en daardoor juist extra kwetsbaarheid voor visserij ontstaat (analoog aan wat hierboven voor kabeljauw is beschreven).

\subsubsection{Voorstel visserijvrije zone vanuit het belang van het kreeftonderzoek}

Op basis van de ruimtelijke patronen van individuele kreeften lijkt het aanleggen van een bufferzone in kavel II met een straal van $\pm 2 \mathrm{~km}$ (de afstand tussen twee monopiles ) rondom de monopile L08 (de paal waaromheen de vier kunstmatige riffen liggen) afdoende waardoor er geen lokale depletie zou kunnen optreden. Deze zone valt net binnen de zone zoals die in 3.2.5 (zie Figuur 7) voor kabeljauw vanuit het belang van het zenderonderzoek is voorgesteld. 


\section{$4 \quad$ Conclusies en aanbevelingen}

\subsection{Natuurinclusief bouwen en medegebruik in WEG Borssele}

In het algemeen lijkt het in de Handreiking gebiedspaspoort Borssele voorgestelde medegebruik binnen verschillende kavels geen nadelen op te leveren voor de voor die kavels eerder vastgestelde doelen voor natuurinclusief bouwen (in het kader van kavelbesluitvoorschriften), uitgezonderd in kavel II (passieve visserij versus doelen voor bevordering van kabeljauw). Daarnaast kunnen "maricultuur" en "duurzame energie" (voorgesteld voor kavel III) nadelen opleveren voor doelen voor bevordering van platte oesters in dezelfde kavel, wanneer daar zeer grootschalig zeewier- of schelpdierkweek zou plaatsvinden of zeer grootschalig zonnepanelen zouden worden geplaatst.

Bij de huidige functietoedelingen liggen er ook synergiekansen met natuurinclusiefbouwen-doelen, met name bij "maricultuur" (voorgesteld voor kavel III). Zeewierkweek en schelpdierkweek (in het bijzonder van platte oesters, vanwege aanvoer van extra oester-recruits) kunnen bijdragen aan doelen voor bevordering van platte oesters in dezelfde kavels.

Er liggen ook synergiekansen die bij de huidige functietoedelingen in de Handreiking gebiedspaspoort Borssele niet kunnen worden benut. Toekenning van de functie "maricultuur" in een kavel met doelen voor bevordering van kabeljauw zou synergie kunnen opleveren bij toepassing van zeewierkweek of schelpdierkweek. Ook passieve visserij en maricultuur kan wellicht goed gecombineerd worden.

Verder zal in het algemeen het aanbrengen van een groter areaal hard substraat in bepaalde kavels middels kabeljauwstructuren of maatregelen voor platte oesterherstel kunnen leiden tot hogere lokale omvang van populaties van bepaalde doelsoorten kunnen (zoals voor kabeljauw en kreeft). Dit kan een uitstraaleffect hebben naar andere kavels waar deze soorten juist worden benut. Met name als er goed inzicht is in welke structuren hard substraat de habitatkwaliteit voor de diverse doelsoorten nog verder vergroten, zal ook de lokale toename in productie/populatie omvang kunnen worden gemaximaliseerd. Alleen directe benutting van doelsoorten op locaties waar deze door natuurinclusiefbouwen worden versterkt, zoals bijvoorbeeld passieve visserij in kavel II, kan de lokale extra productie van doelsoorten, zoals kabeljauw en kreeft, te niet worden gedaan door snelle lokale uitputting, depletie, omdat deze soorten grotendeels honkvast zijn en relatief kleine home ranges hebben. In hoeverre activiteiten die samenhangen met medegebruik ook het gedrag van kabeljauw kunnen verstoren, zoals geluid van extra vaarbewegingen, is nog niet goed bekend. In Borssele kavel II is er dan sprake van tegenstelde belangen, omdat er zowel gewerkt wordt aan het herstel van kabeljauw en kreeft en er tegelijkertijd voorgesteld wordt dezelfde soorten met passieve visserij weg te vangen (Tabel 3).

Maar, zoals al aangegeven, zijn er zeker ook kansen voor synergie. De mogelijke synergieopties die in tabel 2 zijn aangeven zijn hieronder samengevat (Tabel 3).

Tabel 3. Voorgesteld medegebruik en natuurinclusief-bouwen projecten per kavel in Borssele.

\begin{tabular}{|c|c|c|c|c|c|}
\hline $\begin{array}{l}\text { Borssele } \\
\text { kavel }\end{array}$ & Vergunninghouder & Opmerking & $\begin{array}{l}\text { Voorgesteld } \\
\text { medegebruik }\end{array}$ & $\begin{array}{l}\text { Natuurinclusief } \\
\text { bouwen }\end{array}$ & Conclusie \\
\hline I & $\emptyset$ rsted & $\begin{array}{l}\text { Operationeel } \\
\text { sinds } 2020\end{array}$ & $\begin{array}{l}\text { duurzame energie } \\
+ \text { n.t.b }\end{array}$ & kabeljauw & $\begin{array}{l}\text { Geen directe } \\
\text { synergie, maar } \\
\text { natuurherstel en } \\
\text { medegebruik gaan } \\
\text { wel goed samen } \\
\text { (behalve met } \\
\text { passieve visserij) }\end{array}$ \\
\hline II & Ørsted & $\begin{array}{l}\text { Operationeel } \\
\text { sinds } 2020\end{array}$ & passieve visserij & $\begin{array}{l}\text { kabeljauw + } \\
\text { onderzoek }\end{array}$ & $\begin{array}{l}\text { Gevaar voor } \\
\text { wegvissen } \\
\text { doelsoorten }\end{array}$ \\
\hline
\end{tabular}




\begin{tabular}{|c|c|c|c|c|c|}
\hline & & & & $\begin{array}{l}\text { Europese } \\
\text { zeekreeft }\end{array}$ & $\begin{array}{l}\text { natuurherstel. Maar } \\
\text { mogelijk met } \\
\text { visserijvrije zone }\end{array}$ \\
\hline III & Blauwwind & $\begin{array}{l}\text { Operationeel } \\
\text { sinds } 2021\end{array}$ & $\begin{array}{l}\text { maricultuur + } \\
\text { duurzame energie }\end{array}$ & platte oesters & $\begin{array}{l}\text { Natuurherstel en } \\
\text { medegebruik gaan } \\
\text { goed samen, mits } \\
\text { geen zeer } \\
\text { grootschalige } \\
\text { zeewierkweek, } \\
\text { schelpdierkweek of } \\
\text { toepassing } \\
\text { zonnepanelen }\end{array}$ \\
\hline IV & Blauwwind & $\begin{array}{l}\text { Operationeel } \\
\text { sinds } 2021\end{array}$ & $\begin{array}{l}\text { natuurontwikkeling } \\
+ \text { n.t.b }\end{array}$ & platte oesters & Onbekend \\
\hline V & Two Towers & In ontwikkeling & $\begin{array}{l}\text { natuurontwikkeling } \\
+ \text { n.t.b }\end{array}$ & platte oesters & onbekend \\
\hline
\end{tabular}

\subsection{Directe beïnvloeding van passieve visserij op het uitvoeren van het lopende telemetrie-onderzoek naar kabeljauw in kavel II}

- $\quad$ Passieve visserij waarbij (gezenderde) kabeljauwen worden (bij)gevangen kunnen het telemetrie-experiment negatief beïnvloeden

- De kans op vangst van gezenderde kabeljauw is het grootst met visserijmethoden die gericht zijn op benthische vissen, zoals met lijnvisserij of hengel nabij de bodem, of staand want. Maar ook in beaasde kooien kunnen jonge kabeljauwen worden bijgevangen.

- Zelfs als gevangen gezenderde kabeljauw weer worden teruggezet, is er door de kans op barotrauma een negatief effect op het onderzoek tijdens 2021-2022.

- Wanneer we alleen rekening hoeven te houden met de mogelijke effecten op het experiment met de natuurinclusiefbouwenstructuren in het deel van kavel II waar de structuren staan (optie 1 in 3.2.5), lijkt het voor het goed verlopen van het telemetrieonderzoek aan kabeljauw veilig om naast het grid met 16 detectiestations ook de ring met turbines die daar omheen liggen te vrijwaren van visserijen (zie figuur 7. Dit, aangezien individuele kabeljauwen honkvast zijn en zich slechts over geringe afstanden rondom de turbinepalen bewegen (honderden meters).

- Wanneer het natuurinclusiefbouwenproject wordt gezien als - een eerste startpunt - voor het willen bevorderen van kabeljauw in heel kavel II dan wel in beide kavels (I + II) van vergunninghouder Ørsted (optie 2 in 3.2.5), dan zou deze niet gecombineerd moeten worden met passieve visserij op vis (lijnvisserij, staand want)..

\subsection{Directe beïnvloeding van passieve visserij op het uitvoeren van geplande telemetrie-onderzoeken naar Europese zeekreeft}

- $\quad$ Passieve visserij waarbij Europese zeekreeften worden gevangen kunnen het telemetrieexperiment beïnvloeden doordat er gezenderde kreeften worden onttrokken aan het experiment, waardoor het gebruik van de nieuwe typen pijpriffen met en zonder scour protection niet goed onderzocht kan worden en hier geen kennis over wordt gegenereerd of de rendementen voor biodiversiteit en productie kunnen worden bepaald.

- Gevangen gemerkte kreeft zou kunnen worden teruggezet, waarbij er wel kans is op verplaatsing als deze niet op de vangstplaats zelf, of met sterkere stroming wordt teruggezet.

- Voor de kreeft lijkt een tijdelijke visserijvrije zone van $2 \mathrm{~km}$ rond de kunstriffen zelf afdoende. Deze zone is vergelijkbaar met de voorgestelde zone voor kabeljauw in Figuur 7 (valt daar net binnen). Hierbij dient opgemerkt te worden dat er veel minder bekend is over hoe kreeft de harde structuur habitats in offshorewindparken benut in tijd en ruimte dan voor kabeljauw. Voor kreeft is de meeste kennis over ruimtelijk gebruik onderzocht in meer natuurlijke systemen met harde substraten. 


\subsection{Aanbevelingen}

Het is belangrijk om bij natuurinclusief bouwen en medegebruik vooraf goed vast te stellen wat het doel hiervan is. Bijvoorbeeld of deze vooral als pilots fungeren om van te leren voor medegebruik in andere windparken, of dat het hier gaat om op zichzelf staande en effectieve oplossingen moet gaan. Binnen deze pilots zal en goede monitorings- en onderzoeksopzet de kennis kunnen verschaffen om ook voor andere offshore-windparken onderbouwde keuzes hierin te maken. Bij kleinschalige pilots is het dan wel goed om te realiseren dat de schaalgrootte warop iets toegepast wordt, ook het verschil kan uitmaken tussen alleen lokale aggregatie (fungeren als FAD) en daarmee kwetsbaarheid voor visserijen en vergroting van de lokale productie.

Het verdient aanbeveling om de kansen voor synergie zoals in Tabel 2 weergegeven en in Tabel 3 is samengevat nader te beschouwen en uit te werken (dan in deze quickscan mogelijk was).

Ook de schaal waar op natuurinclusief bouwen of medegebruik wordt ingezet en de duur hiervan moet verder worden uitgewerkt. Herstel van natuurlijke platte-oesterriffen gaat om een grotere ruimtelijke schaal en voor lange termijn, terwijl bijvoorbeeld toestaan van passieve visserij ook kortdurend en plaatselijk kan zijn. Ook de schaal-effecten van veel kleine riffen versus enkele grote, of effecten van schaal op productie vergroting (areaal hard substraat) of juist vermindering (onttrekking van voedsel en nutriënten via maricultuur of beschaduwing door grote arealen zonnepanelen) is een belangrijke factor in de keuze voor eventuele vormen van medegebruik en het uitrollen naar andere windparken hiervan.

Verder zullen de hier genoemde ecologische aspecten en overwegingen moeten worden geïntegreerd met logistieke en economische kosten-baten analyses om tot effectieve keuzes bij toepassing van natuurinclusief bouwen en medegebruik van offshorewindparken te komen. 


\section{$5 \quad$ Dankwoord}

Wij willen prof. dr. Peter Herman en prof. dr. Steven Degraer danken voor hun waardevolle suggesties en discussiepunten die zij hebben aangedragen naar aanleiding van een eerdere versie van dit rapport. Verder willen wij dr. Edo Knegtering danken voor zijn inhoudelijke en redactionele suggesties op deze rapportage. Door hun inbreng is de kwaliteit en de leesbarheid van de rapportage verbeterd. 


\section{$6 \quad$ Kwaliteitsborging}

Wageningen Marine Research beschikt over een ISO 9001:2015 gecertificeerd kwaliteitsmanagementsysteem 


\section{Literatuur}

Deelgebruik algemeen

Ministerie van Binnenlandse Zaken en Koninkrijksrelaties. 10 December 2020. Handreiking gebiedspaspoort Borssele https://www.noordzeeloket.nl/publish/pages/188385/handreikinggebiedspaspoort-borssele.pdf

Van den Bogaart, L., Poelman, M., Neitzel, S., Tonk, L., Van der Wal, J.T., Coolen, J., Machiels, M. met bijdrage van Rozemeijer, M., De Boois, I., Vergouwen, S. en Van Duren, L. (2019). Geschiktheid zeewindparken voor maricultuur en passieve visserij: een kwalitatieve beoordeling van geschiktheid van windparklocaties voor voedselproductie. Wageningen University \& Research rapport C044/19. Yerseke: Wageningen Marine Research.

Van den Bogaart, L., Van der Wal , J.T., Tonk, L., Bos, O., Coolen, J., Poelman, M., Vergouwen, S. Van Duren, L., Janssen, H. \& Timmermans, K. (2020). Geschiktheid zeewindparken voor maricultuur en passieve visserij: een kwantitatieve beoordeling van de kansrijkheid van de gebieden voor de potentiële productiviteit van een selectie aan commercieel interessante soorten. Wageningen University \& Research rapport C127/19A. Yerseke: Wageningen Marine Research.

\section{Kabeljauw referenties}

De Troch M, Reubens JT, Heirman E, Degraer S, Vincx M (2013). Energy profiling of demersal fish: a case-study in wind farm artificial reefs. Mar Environ Res. 92:224-33.

Mavraki N, Degraer S, Vanaverbeke J (2021). Offshore wind farms and the attraction-production hypothesis: insights from a combination of stomach content and stable isotope analyses. HYDROBIOLOGIA 848 (7): 1639-1657

Reubens J, Pasotti F, Degraer S, Vincx M. (2013). Residency, site fidelity and habitat use of Atlantic cod (Gadus morhua) at an offshore wind farm using acoustic telemetry. Mar Environ Res. $90: 128-35$.

Reubens J, De Rijcke M, Degraer S, Vincx M. (2013). Diel variation in feeding and movement patterns of juvenile Atlantic cod at offshore wind farms. J Sea Res. 85:214-21.

Reubens J, Braeckman U, Vanaverbeke J, Van Colen C, Degraer S, Vincx M (2013). Aggregation at windmill artificial reefs: CPUE of Atlantic cod (Gadus morhua) and pouting (Trisopterus luscus) at different habitats in the Belgian part of the North Sea. Fish Res. 139:28-34.

Righton D, Quayle VA, Hetherington S, Burt G. (2007). Movements and distribution of cod (Gadus morhua) in the southern North Sea and English Channel: results from conventional and electronic tagging experiments. J Mar Biol Ass UK. 87:599-613.

Van Hal, R., Couperus, B., Fassler S., Gastauer, S., Griffioen, A.B., Hintzen, N., Teal, L., Van Keeken, O.A., Winter, H.V., 2012. Monitoring- and Evaluation Program Near Shore Wind Farm (MEPNSW): Fish community. IMARES Report C059/12, OWEZ_R264_T120120507_final_report_fish.

Van Hal R, Griffioen AB, Van Keeken OA (2017). Changes in fish communities on a small spatial scale, an effect of increased habitat complexity by an offshore wind farm. MARINE ENVIRONMENTAL RESEARCH 126: 26-36

van der Knaap I, Slabbekoorn H, Winter HV, Moens T, Reubens J (2021). Evaluating receiver contributions to acoustic positional telemetry: a case study on Atlantic cod around wind turbines in the North Sea. Animal Biotelemetry. In press.

van der Knaap I, Reubens J, Thomas L, Ainslie M, Winter HV, Hubert J, Martin B, Slabbekoorn H (2021). Effects of a seismic survey on movement of free-ranging Atlantic cod. Current Biology. In press.

Winter, H.V., Aarts, G., van Keeken, O.A., (2010). Residence time and behaviour of sole and cod in the Offshore Wind farm Egmond aan Zee (OWEZ). IMARES Report C038/10, NoordzeeWind report number OWEZ_R_265_T1_20100916. 


\section{Europese zeekreeft referenties}

Agnatt, A-L., Kristiansen T. S., and Jorstad K. E. 2007. Growth, reproductive cycle, and movement of berried European lobsters (Homarus gammarus) in a local stock off southwestern Norway. - ICES Journal of Marine Science, 64: 288-29.

Bannister, RC.A, J.T. Addison and S.R.J. Lovewell. 1994. Growth, movement, recapture rate and survival of hatchery-reared lobsters (Homarus gammarus, Linnaeus, 1758) released into the wild on the English east coast. Crustaceana. 67: 156-172.

Bannister RCA, Howard AE (1991) A large-scale experiment to enhance a stock of lobster (Homarus gammarus L.) on the English east coast. ICES Mar Sci Symp 192:99-170

Cleveringa J., F. van Vliet, J.H. Bergsma, R.J. Jonkvorst; Bureau Waardenburg (2012). Zandwinning op de Zeeuwse banken. Onderzoek naar effecten op ecologische en aardkundige waarden en Kostenaspecten. Bureau Waardenburg rapport 11-180.

Cobb, J.S. (1971) The shelter related behavior of the lobster Homarus americanus. Ecology, 52,108115.

Galparsoro I, Borja Á, Bald J, Liria P, Chust G (2009) Predicting suitable habitat for the European lobster (Homarus gammarus), on the Basque continental shelf (Bay of Biscay), using EcologicalNiche Factor Analysis. Ecological Modelling 220:556-567

Howard, A.E. (1980). Substrate and tidal limitations on the distribution and behaviour of the lobster and edible crab. Prog. Underwat. Sci . 5: 165-9.

Howard, A.E. 1988. Lobster behaviour, population structure and enhancement. Symposium of the Zoological Society of London. 59: 355-364.

Howard A.E., R.S. Nunny (1983), Effects of near-bed current speeds on the distribution and behaviour of the lobster, Homarus gammarus (L.). Journal of Experimental Marine Biology and Ecology 71: 27-42, ISSN 0022-0981, https://doi.org/10.1016/0022-0981(83)90102-8.

Jensen A.C., Wickins J., Bannister C. (2000). The Potential Use of Artificial Reefs to Enhance Lobster Habitat. Chapter 23 in Artificial Reefs in European Seas - 2000; Jensen A.C., Collins K.J., Lockwood A.P.M. (Eds), Springer Science \& Business Media.

Jensen, A C., K.J. Collins, E.K. Free and R.CA. Bannister. 1994. Lobster (Hamarus gammarus) movement on an artificial reef; the potential use of artificial reef for stock enhancement. Crustaceana. 67(2): 198-211.

Karnofsky, E. B., Atema, J., and Elgin, R. H. (1989). Field observations of social behavior, shelter use and foraging in the lobster, Homarus americanus. Biol. Bull. (Woods Hole, Mass.) 176, 239-246.

Karnofsky, E. B., Atema, J., and Elgin, R. H. (1989b). Natural dynamics of population structure and habitat use of the lobster, Homarus americanus, in a shallow cove. Biol. Bull. (Woods Hole, Mass.) 176, 247-256.

Karnofsky E. B. \& Price H.J. (1989) Dominance, territoriality and mating in the lobster, Homarus americanus: A mesocosm study, Marine Behaviour and Physiology, 15:2, 101-121, DOI: 10.1080/10236248909378722

Lees K.J., Aileen C. Mill, Daniel J. Skerritt, Peter A. Robertson, Clare Fitzsimmons (2018). Movement patterns of a commercially important, free-ranging marine invertebrate in the vicinity of a bait source. Animal Biotelemetry 6: 8 1-12 https://doi.org/10.1186/s40317-018-0152-4

Lees KJ, Mill AC, Skerritt DJ, Robertson PA, Fitzsimmons C (2020) Spatial overlap, proximity, and interaction between lobsters revealed using acoustic telemetry. Mar Ecol Prog Ser 645:109-124. https://doi.org/10.3354/meps13376

Martin J, Tolon V, Van Moorter B, Basille M, Calenge C (2009) On the use of telemetry in habitat selection studies. Barcula D, Daniels J (eds) Telemetry: research, technology and applications. Nova Science Publishers, New York, NY, p 37-55.

Mavraki Ninon, Steven Degraer, Tom Moens, Jan Vanaverbeke, 2020. Functional differences in trophic structure of offshore wind farm communities: A stable isotope study. Marine Environmental Research 157, 104868, ISSN 0141-1136

MinIenW Handreiking gebiedspaspoort windenergiegebied Borssele met zoneringskaart voor medegebruik 20201209.

Moland E, Moland Olsen E, Knutsen H, Knutsen JA, Enersen SE, André C, Stenseth NC (2011a) Activity patterns of wild European lobster Homarus gammarus in coastal marine reserves: implications for future reserve design. Mar Ecol Prog Ser 429:197-207. https://doi.org/10.3354/meps09102

Moland, E., Olsen, E. M., Andvord, K., Stenseth, N. C., \& Knutsen, J. A. (2011b). Home range of European lobster (Homarus gammarus) in a marine reserve: Implications for future reserve 
design. Canadian Journal of Fisheries and Aquatic Sciences, 68, 1197-1210.

https://doi.org/10.1139/f2011-053

Moland, E, Carlson, SM, Villegas-Ríos, D, Ree Wiig, J, Moland Olsen, E. (2019). Harvest selection on multiple traits in the wild revealed by aquatic animal telemetry. Ecol Evol 9: 6480-6491. https://doi-org.ezproxy.library.wur.nl/10.1002/ece3.5224

Picciulin M. , M. Umani, M. Costantini, M. Spoto and E.A. Ferrero. (2003). Acoustic tracking methods in the Natural Marine Reserve of Miramare: monitoring the movements of target species inside a marine protected area, a case study. Bollettino di Geofisica Teorica ed Applicata Vol. 44: 27-32.

Rozemeijer M.J.C., van de Wolfshaar K.E. (2019). Desktop study on autecology and productivity of European lobster (Homarus gammarus, L) in offshore wind farms. Wageningen Marine Research report C109/18. KB-30: Resource Use Efficiency (project no. KB-30-002-011).

Sissingh J. (2020). Handreiking gebiedspaspoort Borssele. Verkenning medegebruik Windenergiegebied Borssele. Pondera Consult Rapport 720109, 12-10-2020.

Skerritt, D.J. (2014) Abundance, interaction and movement in a European Lobster Stock. Newcastle University. MSc Thesis School of Marine Science and Technology.

Skerritt DJ, Robertson PA, Mill AC, Polunin NVC, Fitzsimmons C (2015) Fine-scale movement, activity patterns and home-ranges of European lobster Homarus gammarus. Mar Ecol Prog Ser 536:203219. https://doi.org/10.3354/meps11374

Smith IP, Collins KJ, Jensen AC (1998) Movement and activity patterns of the European lobster, Homarus gammarus, revealed by electromagnetic telemetry. Mar Biol. 132: 611-623

Smith, I.P., Collins, K.J., Jensen, A.C., 1999. Seasonal changes in the level and diel pattern of activity in the European lobster, Homarus gammarus (L.). Mar. Ecol. Prog. Ser. 186, 255-264.

Smith, I.P., Collins, K.J. and Jensen, A.C. 2000. Digital electromagnetic telemetry system for studying behaviour of decapod crustaceans. J. Exp. Mar. Biol. Ecol. 247: 209-222.

Smith IP, Jensen AC, Collins KJ, Mattey EL (2001) Movement of wild European lobsters Homarus gammarus in natural habitat. Mar Ecol Prog Ser 222:177-186

Thorbjørnsen SH, Moland E, Huserbråten MBO, Knutsen JA, Knutsen H, Olsen EM (2018) Replicated marine protected areas (MPAs) support movement of larger, but not more, European lobsters to neighbouring fished areas. Mar Ecol Prog Ser 595:123-133. https://doi-

org.ezproxy.library.wur.nl/10.3354/meps12546

van der Meeren GI (1997) Preliminary acoustic tracking of native and transplanted European lobsters (Homarus gammarus) in an open sea lagoon. Mar Freshw Res 48: 915-921.

Walter, I. , Saborowski, R. and Buchholz, F. (1998): The influence of shelter and light on locomotive activity rhythms and walking distances of juvenile Helgoland lobsters (Homarus gammarus), Zoology 101, Supplement I (DZG 91.1).

Wiig, J., Moland, E., Haugen, T. O., \& Olsen, E. M. (2013). Spatially structured interactions between lobsters and lobster fishers in a coastal habitat: Fine-scale behaviour and survival estimated from acoustic telemetry. Canadian Journal of Fisheries and Aquatic Sciences, 70, 1468-1476.. 


\section{Verantwoording}

Rapport C060/21

Projectnummer: 4318100323

Dit rapport is met grote zorgvuldigheid tot stand gekomen. De wetenschappelijke kwaliteit is intern getoetst door een collega-onderzoeker en het verantwoordelijk lid van het managementteam van Wageningen Marine Research

Akkoord:

S. Smith

Onderzoeker

Handtekening:

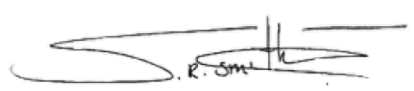

Datum: $\quad 8$ juli 2021

Akkoord:

J. Asjes

Manager integratie

Handtekening:

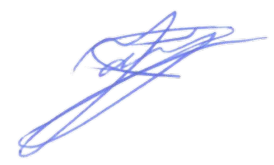

Datum:

8 juli 2021 
Wageningen Marine Research

T: $+31(0) 317480900$

E: marine-research@wur.nl

www.wur.nl/marine-research

Bezoekers adres:

- Ankerpark 271781 AG Den Helder

- Korringaweg 7, 4401 NT Yerseke

- Haringkade 1, 1976 CP IJmuiden
Wageningen Marine Research levert met kennis, onafhankelijk wetenschappelijk onderzoek en advies een wezenlijke bijdrage aan een duurzamer, zorgvuldiger beheer, gebruik en bescherming van de natuurlijke rijkdommen in zee-, kust- en zoetwatergebieden.
Wageningen Marine Research is onderdeel van Wageningen University \& Research. Wageningen University \& Research is het samenwerkingsverband tussen Wageningen University en Stichting Wageningen Research en heeft als missie: 'To explore the potential of nature to improve the quality of life' 